\title{
Sorting it Out: \\ The Effects of Charter Expansion on Teacher and Student Composition at Traditional Public Schools
}

\author{
Lucy C. Sorensen* Stephen B. Holt ${ }^{\dagger}$
}

March 24, 2021

\begin{abstract}
Since their introduction in the 1990s, charter schools have grown from a small-scale experiment to a ubiquitous feature of the public education landscape. The current study uses the legislative removal of a cap on the maximum number of charters in North Carolina as a natural experiment to assess the impacts of charter school growth on teacher quality and student composition in traditional public schools (TPS) at different levels of local market penetration. Using an instrumental variable difference-in-differences approach to account for endogenous charter demand, we find that intensive local charter entry reduces the inflow of new teachers at nearby TPS, leading to a more experienced and credentialed teaching workforce on average. However, we find that the entry of charters serving predominantly White students leads to reductions in average teacher experience, effectiveness, and credentials at nearby TPS. Overall these findings suggest that the composition of the teacher workforce in TPS will continue to change as charter schools further expand, and that the spillover effects of future charter expansion will vary by the types of students served by charters.
\end{abstract}

Keywords: Charter schools, school choice, teacher labor market, teacher quality

\footnotetext{
*Assistant Professor, Rockefeller College of Public Affairs and Policy, University at Albany, SUNY. Email: lsorensen@albany.edu.

${ }^{\dagger}$ Assistant Professor, Rockefeller College of Public Affairs and Policy, University at Albany, SUNY. Email: sbholt@albany.edu
} 


\section{Introduction}

School choice refers to the ability of students and their families to choose among a variety of different local schooling options, including traditional public schools (TPS), private schools, and charter schools. The proliferation of choice affects more than just students and their families, however. It also affects teachers, who face an increasingly diverse array of employer options within commuting distance of their residence. In particular, the growth and maturation of charter schools in urban and suburban communities allows teachers to choose from a variety of schools serving different types of students and using different models of operation. The question of how student access to high quality instruction changes as the charter sector expands, and as teachers and students jointly shift their sorting patterns across schools, remains largely unanswered. This question is central to informing the broader debate of whether charter schools serve to promote the quality of public education - or to interfere with it (Gleason, 2019; Ladd, 2019).

In North Carolina, while the entry of the first charter schools revealed modest effects on teacher sorting (Jackson, 2012), the number of charter schools available to teachers and families within the same community has increased dramatically. In this study, we return to the question of how continued charter sector growth influences the sorting patterns of teachers and students. We do so with attention toward how spillover effects of charters may differ between the extensive margin, when the first charter school enters a local education system, and the intensive margin, when the share of students in the local education system enrolled in charter schools grows large. We also do so with attention to how spillover effects of a charter school may vary based on the demographics of students enrolling in the charter.

Introducing intra-district competition in the provision of education services has been a policy tool aimed at improving school performance for many decades (Friedman, 1997). Generally, the logic that motivates school choice policies posits that increased competition for students and, indirectly, funding will drive traditional public schools to be more efficient in their use of resources and thereby more effective in teaching students Abdulkadiroğlu 
and Sönmez, 2003; Hoxby, 2003). Since Minnesota adopted the first policy allowing local education agencies to provide privately-operated charter schools public funding, a large empirical literature has arisen seeking to test the effectivenss of charters in improving student performance (see Hanushek and Rivkin, 2006; Berends, 2015; Betts and Tang, 2014; Cheng et al., 2017 for reviews), and generally provides mixed evidence?

In recent years, as charter schools have grown in number and matured in operations, scholars have examined their effects on other aspects of the education system, including their impacts on student sorting across schools (e.g., Buckley and Schneider, 2005, Dee and Fu, 2004; Lacireno-Paquet et al., 2002; Ladd et al., 2017; Zimmer and Guarino, 2013; Winters, 2015; Winters et al., 2017) and local teacher labor markets (e.g., Bruhn et al., 2020; Carruthers, 2012b a; Jackson, 2012). Using updated data from North Carolina public schools, we examine the impact of recent legislative deregulation of the North Carolina charter school sector on charter expansion. Further, as this legislative change preceded a large increase in charter school entry and change in the types of charter schools entering, we examine the effects of the resulting increase in charter school options on nearby traditional public school (TPS) teacher and student movement and characteristics. We hypothesize that the general equilibrium effects of growing charter share on local education systems could be quite different than the marginal effects of a single charter school entry.

Specifically, this study uses administrative data from North Carolina students, teachers, and schools, from 2006 to 2016 to assess the continuous effects of charter school entry as charters move from a small share of education providers to a more meaningful share after

\footnotetext{
${ }^{1}$ Evidence from lottery assignment of oversubscribed charters in Boston and KIPP schools in New York City generally demonstrates that some charter schools have large effects on students achievement, particularly for students of color and economically disadvantaged students (Angrist et al., 2002 Hoxby and Rockoff, 2005. Abdulkadiroglu et al., 2009; Hoxby et al., 2009: Dobbie and Fryer, 2011; Angrist et al., 2010; Abdulkadiroğlu et al. 2011). However, lottery studies using a national sample show considerable variation in the relative efficacy of charter schools and, in the aggregate, negligible differences Tuttle et al. (2012); Gleason et al. (2010); Clark et al. (2015) and quasi-experimental evidence is similarly inconclusive (Bifulco and Ladd, 2006) Sass, 2006: Zimmer et al., 2009, 2012). The weight of evidence does suggest academically focused charters have large, positive impacts on disadvantaged students (Clark et al., 2015, Cheng et al., 2017; Cohodes, 2018). Prior work shows similarly inconclusive evidence of charter impacts on TPS efficacy (Hoxby, 2003 Bifulco and Ladd, 2006: Gilraine et al. 2020; Sass, 2006, Booker et al., 2008, Ni, 2009, Zimmer and Buddin, 2009: Imberman, 2011, Winters, 2012, Zimmer et al., 2009).
} 
the removal of a charter cap, particularly in urban and suburban areas of the state. In these areas, we calculate the number of charters with a 10-mile radius of each traditional public school in each year, as well as characteristics of the student populations of each charter within that 10 -mile radius. We then estimate the effect of increased charter school openings on TPS teacher and student characteristics using both a conventional two-way fixed effects (TWFE) approach and an instrumental variable difference-in-differences (IV-DiD) approach.

Given the potential endogeneity of charter expansion siting decisions, our IV-DiD approach resembles the approach taken by Ridley and Terrier (2018) in which we use the interaction of latent demand for charter schools - as measured by the number of new charter applications submitted within a 10-mile radius of a TPS at the start of the post-period - and a post-period indicator, as an instrument for the number of charters that ultimately open within that radius. This approach accounts for the endogenous nature of charter school opening locations to identify the local average treatment effect of charter entry and expansion on TPS outcomes. Since the cap removal expanded both the number of TPS exposed to at least one charter (extensive margin) and the number of additional charters nearby some TPS (intensive margin), we estimate the effects of the cap removal on both the extensive and intensive margins separately.

Our results indicate three general trends resulting from relaxed regulations of the charter sector. First, we confirm a trend noted in an earlier study (Ladd et al., 2017) that the number of charter schools in the state grows substantially following cap removal and many of the entering charter schools serve primarily White and economically-advantaged students, which could have differential impacts on teachers than found in studies using earlier data from the state (Carruthers, 2012a; Jackson, 2012).

Second, we show that increases in both the intensity of charter entry and type of charters entering an area demonstrably change the composition of nearby TPS's students and teachers. Regarding students, more intensive entry of charters increases total enrollments at nearby TPS, and may increase the share of students White or economically disadvan- 
taged. Regarding teachers, we observe that as new charter schools open within 10 miles, TPS struggle to recruit new teachers. More specifically, each additional charter opening near a TPS decreases the proportion of novice teachers entering the school and increases average teacher experience and the proportion of teachers with advanced degrees. The gains in average teacher experience at TPS attributable to continued charter entry does not translate, however, into increases in average teacher effectiveness.

Third, we find that the type of charter entry matters. Nearby charters serving predominantly White students lead to the loss of veteran teachers in nearby TPS and increased reliance on novice teachers without advanced degrees. In many TPS, the opening of an predominantly White charter nearby also implies a drop in average teacher effectiveness, as measured by value-added in reading and math. Our finding that the competitive effect of charters on teacher sorting varies by charter type, in this case by the composition of the student body at entering charters, echoes recent work by Gilraine et al. (2020), who adopt a similar methodological approach in North Carolina and find that the competitive effects of charter entry on TPS performance varies by the type of academic program operated by the entering charter.

Through these patterns, our study shows how teachers and students in TPS respond to not just a single charter school opening nearby, but to the advanced expansion and diversification of charters in the area. It also shows that spillover effects from one type of charter do not generalize to other types of charters, and that the entrance of charter schools targeting White students proves especially problematic for existing TPS. In the following sections, we first summarize the growing literature on charter schools in Section 2, focusing in particular on spillover effects onto traditional public schools in terms of students, teachers, and resources. That section also provides contextual details on charter schools and policy changes in North Carolina during the period of study. We then describe our data and empirical approach in Sections 3 and 4. Finally, we present results in Section 5 and provide a concluding discussion in Section 6 . 


\section{Literature Review}

\subsection{Spillover effects of charter schools}

Critics and scholars have raised concerns regarding the impact of charter school introduction on equity and access for disadvantaged, low-income, and special needs students (Winters, 2015). Here, three different concerns arise regarding charters and equity. First, given the need for both enrolling students and maintaining positive value-added to continue operation, charters might face a financial incentive to "cream-skim" (i.e., admit only promising students) or "push out" (i.e., nudge low achieving, special education, or disadvantaged students to exit) students. Indeed, descriptive comparisons of charters nationally often suggest that charters enrolled fewer special education students than their TPS peers (Cremata et al. 2013). However, Zimmer et al. (2009) use data from eight different school districts and compare the lagged achievement of students entering charters with their peers to show that overall, there is no significant difference, which suggests no "cream-skimming" on average. They note, however, that white students who attend charters do tend to be higher achieving students. Winters (2015) use data from Denver to examine the possibility of "push out" among charters. They find no systematic difference in the likelihood of exit among special education students in charter and TPS schools. Instead, their results suggest that descriptive differences between charter and TPS in special education enrollments arise through charters' lower likelihood of classifying students as special education and non-special education students entering charter schools at higher rates (see also Winters et al., 2017; Zimmer and Guarino, 2013).

The differences in enrollment of special education students may reflect charters engaging in selective enrollments. Bergman and McFarlin Jr (2018) conducted an audit study of charter schools and TPS districts in 29 states and Washington, D.C. in which they emailed the schools for enrollment information for a fictional student. In the emails, they randomly assigned suggestions of behavioral issues (e.g., an IEP reference or reference to bad grades) 
and found that charter schools, including high performing charter schools, were less likely to respond to requests that referenced an IEP (an effect that was mitigated by funding policies that reimburse schools for special education costs). Collectively, the evidence suggests that charters are possibly more likely to engage in opportunistic enrollment behavior, but this gaming behavior varies by policy context.

Second, the very mechanism of competition for public resources through enrollment driven funding for charter schools raises concerns that charters may divert resources from TPS, particularly those serving disadvantaged students, further exacerbating funding inequities. The literature investigating this possibility is more limited, but suggests charter entry carries significant negative impacts on TPS revenues (Dee and Fu, 2004; Bifulco and Reback, 2014; Ladd and Singleton, 2017). For instance, using school-level data from Arizona, Dee and Fu (2004) observe an increase in TPS student-teacher ratios associated with charter entry, suggesting TPS may lose resources to charter schools (see also Bifulco and Reback, 2014 for a detailed description of the fiscal impact in Albany and Buffalo).

More recently, Ladd and Singleton (2017) use detailed line-item expenditure data from select urban and non-urban districts in North Carolina and estimate a negative fiscal impact for TPS of about $\$ 1,000$ per charter student in urban schools and $\$ 370$ per charter student in non-urban schools. They note the effects are attributable to a structural difference between the rate of revenue loss to charter enrollment and rate of expenditure in TPS. Theoretically, the loss of revenue could motivate TPS districts to reallocate resources toward instruction and teacher salaries to better compete with charters. However, Arsen and Ni $(2012)$ analyze data from Michigan and find both that charter entry negatively affects TPS revenues, and that districts experiencing a loss do not alter their expenditure patterns in response to charters. Similarly, Cook (2018) uses panel data from Ohio to investigate the impact of charter entry on TPS resources. Cook finds that charter entry reduces enrollments and property values in nearby TPS, and TPS respond to the ensuing revenue decline by reducing expenditures on teaching through layoffs, generally of younger teachers. In a related analysis, Ridley and 
Terrier (2018) exploit a policy change in Massachusetts to estimate the fiscal impact of charter expansion on TPS. As Ridley and Terrier point out, Massachusetts includes a provision that provides transitional funding to districts that lose enrollment to charters, so as to mitigate the potential for enrollment-driven fiscal impacts that undermine expenditures on teaching. They find that charter entry in Massachusetts increases revenue for TPS, and TPS shift expenditures away from administration and toward instruction and teacher salaries. Taken together, the results suggest that districts face structural impediments to adjusting to charter entry that must be accounted for in policies expanding the charter sector.

Finally, scholars have noted the possibility that bias in parental preferences may lead to systematic student sorting by race into charter schools in a manner that exacerbates demographic and socioeconomic segregation of students. Descriptively, drawing on student- and school-level data from 27 states, Cremata et al. (2013) show charters schools disproportionately serve black and Latinx students and generally have lower proportions of white students than TPS. Similarly, charters nationally enroll a higher share of economically disadvantaged students. Indeed, evidence suggests charter entry led to increased racial segregation of schools in Philadelphia and Texas (Zimmer et al., 2009), Arizona (Dee and Fu, 2004), Michigan (Ni, 2012), and North Carolina (Ladd et al., 2017). Nationally, increased charter penetration in a district is associated with increased socioeconomic segregation across schools in the district (Marcotte and Dalane, 2019). Particularly relevant to the current study, Ladd et al. (2017) examine student demographics across TPS and charter schools after the legislative removal of the cap on the number of allowable charter schools. They show that charter entry and expansion has lead, over time, to both the self-segregation of black students (consistent with prior evidence from Bifulco and Ladd, 2007) and a growth in the number of charter schools serving primarily high-achieving white students. However, their analytical time frame ends in 2012, just prior to the full implementation of the cap removal. We aim to extend this work by including data after the substantial expansion of the charter sector post-cap-removal, and by considering causal effects on teacher sorting in particular. 


\subsection{Charter schools and teacher sorting}

Given the early theoretical and rhetorical focus of charter school policies on decreasing student achievement gaps and improving school quality, much of the research has examined the impacts of charter entry and operations on student outcomes (e.g., achievement, graduation, sorting). However, charter school expansion has also likely shaped how teachers sort across schools, how they are supported and developed professionally, and which types of teachers enter and leave the profession.

Among TPS teachers, scholars have long observed that schools serving more advantaged students have lower teacher turnover (Feng, 2010; Hanushek et al., 2004), teachers with better credentials and more experience (Clotfelter et al., 2005, 2006), and more effective teachers (Mansfield, 2015; Sass et al., 2012; Glazerman et al., 2011; Isenberg et al., 2016; Steele et al., 2015). Moreover, Boyd et al. (2008) show that in New York City, low-performing schools lose effective teachers to higher-performing schools and Steele et al. (2015), using data from a large urban district in the south, find that schools serving high proportions of minority students lose teachers at a higher rate to nearby schools with fewer minority students. Collectively, the evidence from within- and across-district teacher sorting in TPS suggests many teachers have preferences for school environments that shape the distribution of quality teachers across schools. The entry and expansion of charters further increases the range of options teachers face for employment, particularly given the different policy regime governing charter operations.

A growing body of work has begun to consider the implications of charter sector growth for teacher labor markets and the distribution of teachers across schools. For instance, using North Carolina data from 1997 to 2009, Carruthers (2012b) observes that teachers in charter schools are less likely to hold a graduate degree, come from a competitive college, or have regular certification, and are more likely to be novice teachers. Moreover, while teachers who leave TPS for charters tend to be as or less effective relative to those who stay, more effective TPS teachers go to higher achieving charter schools. That is, the patterns 
of teacher sorting resemble those observed by Boyd et al. (2008) in New York TPS, and may contribute to inequity in access to quality teachers for disadvantaged students. Further, in a follow-up study using the same data, Carruthers (2012a) finds that charters experience much higher turnover than TPS in their early years of operations, and while the gap narrows over time and charters improve their retention of more experienced teachers, charter teacher turnover remains much higher than TPS turnover. However, recent evidence from a charter policy reform in Massachusetts suggests that high-performing charters can maintain high performance even when expanding operations and using a relatively inexperienced workforce (Cohodes et al., 2019). Finally, Jackson (2012) uses data from North Carolina (1995-2005) to investigate the impact of charter entry on teacher mobility and wages at the nearest TPS: ${ }^{2}$ He provides compelling evidence that although charter entry does not appreciably impact TPS teacher mobility overall, in schools with high proportions of disadvantaged students, TPS hired fewer new teachers and saw a modest decrease in teacher quality. He also found that charter entry induces modest, but significant, increases in salaries for TPS teachers in North Carolina (Jackson, 2012).

The emerging evidence about charter schools suggests that a large and growing charter market might further exacerbate within-district trends of schools with relatively advantaged students attracting and retaining the most qualified and effective teachers, widening inequality in access to quality teachers across schools. On the one hand, the combined effects of student and teacher sorting into schools of choice might yield substantial segregation of both teachers and students. Given the long observed preference for teachers to transfer to schools serving Whiter, more advantaged students, and the growing evidence that charter schools often increase racial and economic segregation across schools, the expansion of the charter sector may be acutely felt by TPS serving disadvantaged students in teacher recruitment

\footnotetext{
${ }^{2} \mathrm{~A}$ more recent paper (Gao and Semykina, 2020) also examines the effects of charter growth on teachers, and similar to Jackson (2012) uses data from before the time of the charter cap removal. They instrument for the current number of charters with the historical number of charters. They find increases in the average credentials of teachers from increased charter competition, but do not consider heterogeneous effects of different types of charters.
} 
and retention.

On the other hand, the operational autonomy granted charter schools allows for the retention of teachers who do not have regular certification, who are more likely to be Black (Carver-Thomas and Darling-Hammond, 2017) and more likely to exit the profession early in their careers (Boyd et al., 2006). Given the benefits from diversifying the teacher workforce (e.g., Dee, 2005; Gershenson et al., 2016; Holt and Gershenson, 2017; Putman et al., 2016; Gershenson et al., 2018, Vinopal and Holt, 2019) and the barriers to entry posed by expensive certification requirements (Carver-Thomas and Darling-Hammond, 2017), growth in the charter sector may allow for the development and retention of a more diverse pipeline of teachers. Recent work by Bruhn et al. (2020) examines teachers in charters and TPS in Massachusetts and finds that effective teachers in charters frequently exit to TPS after obtaining a license, consistent with teachers responding to costly certification requirements by sorting into charter schools early in their careers.

We build on this literature by using the cap removal in North Carolina as a natural experiment to investigate the impacts of nearby charter school growth on TPS teacher turnover, characteristics, and effectiveness, as the local education market moves towards both a much higher number of, and a different form of, charter schools.

\subsection{Charter schools in North Carolina}

In North Carolina, the context surrounding the politics and policy of school choice has been fraught with concern about race-based segregation and discriminatory practices (Ladd) et al., 2017). Charlotte-Mecklenburg, among the largest school districts in North Carolina, operated under court ordered desegregation of public schools from 1972 to 2002 Jackson, 2009). Thus, in 1996, when passing legislation that enabled the establishment of charter schools, in addition to a cap of 100 allowable charter schools, legislators included provisions to ensure charter schools were demographically representative of their surrounding communities and disallowed racial discrimination in admissions to assuage fears that the introduction of 
choice would undermine efforts toward racial integration in public schools (Ladd et al., 2017).

In 2011, motivated in part by the pursuit of federal funding through the Obama administration's Race to the Top program, legislators revisited the laws governing charter school operations in North Carolina and removed the cap of 100 allowable charter schools and increased allowable annual enrollment growth at existing charters (McCraw et al., 2011). The Department of Public Instruction also introduced a process for expedited review of charter applications (called "Fast Track") to accelerate the timeline for opening a subset of new charter schools (McCraw et al., 2016) $!^{3}$ The substantial changes to the restrictions placed on the charter sector in North Carolina was followed by a notable increase in the number of applications to open new charter schools in the state (Ladd et al., 2017), but only in recent years have the changes been in effect for long enough to observe the opening of new schools and their impacts on teacher and student sorting between TPS and charters.

$$
\begin{aligned}
& <<<\text { Figure 1 about here }>>> \\
& <<<\text { Figure 2 about here }>>>
\end{aligned}
$$

Figure 1 and Figure 2 draw on data from the North Carolina Education Research Data Center (NCERDC) to capture the effect of the legislative removal of the charter cap in North Carolina on the size of the charter exposure and the extent of charter competition TPS face over time. As shown in Figure 1, a simple count of the number of charters operating in the state demonstrates a significant scaling up of the charter sector over time, particularly in recent years. Between the effective removal of the charter cap in 2012 and 2016, the number of charters operating in North Carolina increased by $60 \%$, a sizable change in a relatively

\footnotetext{
${ }^{3}$ The charter application process typically requires the following steps. First, an application must be sent to the Office of Charter Schools one year prior to opening for Fast-Track applicants, and two years prior for traditional applicants. The Charter School Advisory Board then makes recommendations to the State Board of Education, who may grant a planning year for the proposed charter if the following requirements are met: (1) the applicant has the ability to operate the school in an educationally and economically sound manner, and (2) granting the application would improve student learning and would achieve one of the other purposes set out in NCGS115-218. Applications must include, among other items, a mission statement, a governance plan, and a financial plan. Applicants must also indicate how they would comply with various state and federal regulations, such as provision of transportation to school and compliance with the Individuals with Disabilities Education Act
} 
short time period. Moreover, focusing on urban and suburban districts, Figure 2 presents the full distribution of the number of charter schools within 10 miles of each TPS school in 2012 (year of cap removal) shown in black outline and 2016 (four years after cap removal) shown in light blue fill. This graph illustrates how the cap removal led to dramatic changes in TPS exposure to nearby charter schools at both the extensive and intensive margins. At the extensive margin, the proportion of TPS with no charters within a 10 mile radius decreased from approximately 25 percent to approximately 15 percent. At the intensive margin, the proportion of TPS with a large number of charters within a 10 mile radius grew rapidly. As of 2012, the maximum number of charters within the given radius was 10 schools; by 2016 it was 24 schools. Our research design explicitly uses both the extensive and intensive forms of variation to identify effects on TPS students and teachers.

$$
<<<\text { Figure } 3 \text { about here }>>>
$$

The legislation removing the cap on the number of allowable charters was accompanied by a relaxation of diversity and inclusion requirements, allowing charters to explicitly target specific subgroups of students, such as gifted, economically disadvantaged, or special education students. Figure 3 depicts the count of new charters opening each year by their racial composition. Predominantly White charters are those with more than 80 percent of students White, predominantly non-White charters are those with more than 80 percent of students Black, Hispanic, or other race, and mixed charters are those with any other student racial composition. Consistent with prior evidence from North Carolina on the selection patterns of both Black and White parents' preferences for more same-race peers (e.g., Bifulco and Ladd, 2006), the initial wave of charter openings after cap removal and relaxing accessibility requirements includes many charters that are predominantly White or predominantly non-White alongside a large increase of racially mixed charters. 4

\footnotetext{
${ }^{4}$ Similar patterns emerge when considering the socioeconomic status of students in entering charters, as a large number of charters entering after the cap removal serve predominantly economically advantaged students Figure A1). However, charter schools are not legally required to participate in the National School Lunch program, and economic advantage/disadvantage is defined using FRPL eligibility. Thus,
} 
Clearly, the descriptive trends outlined here reveal a sizable shift in both the number of new charters entering North Carolina, their geographic density in proximity to other schools, and the families to which they cater after the removal of the charter school cap and broader relaxation of regulations governing charters. For parents and teachers, who may be unable or unwilling to move to a new neighborhood and community to change schools alone, the new wave of charter entry presents a large variety of options within the same area, reducing the cost of switching schools. For teachers, each new charter presents a new potential employer, with different workplace cultures, licensing policies, and student bodies that may appeal to their unique preferences, all within the commuting radius of their current home. For students and families, the growth in charter density offers a similarly broad array of options that vary in peer composition, quality, programming, and focus.

Of course, in light of North Carolina's history described above, and prior evidence of difficulty recruiting and retaining teachers at high-needs public schools more broadly (e.g., Sass et al., 2012; Steele et al., 2015), biased preferences among both teachers and parents might lead to systematic sorting that results in racially and socioeconomically segregated schools. Indeed, the entry of predominantly White and predominantly non-White charter schools portends precisely such an outcome. We exploit this expansion of different types of charters, at the extensive and intensive margins, to examine any heterogeneous effects on teacher and student composition at nearby TPS.

\section{Data}

Our dataset is composed of a variety of student-level, teacher-level, and school-level administrative records provided by the North Carolina Education Research Data Center (NCERDC). We restrict our analytical sample to the 2005-2006 to 2015-2016 school years for which we have course membership data, which can exactly match students to specific classrooms and

many charters in our data report having no free and reduced-price lunch eligible students, and we cannot distinguish between true zeroes and missing data. For this reason, we concentrate instead on charters that serve more racially homogeneous student bodies in our analysis. 
teachers. This eleven-year panel dataset conveniently includes six years of data prior to the removal of the charter cap in North Carolina, and five years of data after the removal of the charter cap.

In general, the data reported by charter schools is far less consistent and less comprehensive than the data reported by traditional public schools, a fact noted by prior research Carruthers, 2012b; Jackson, 2012). Charter schools are required by law to provide data on test score proficiency results, but not the more detailed information on teachers and classrooms. We address this sample selection issue primarily by aggregating data in a way that focuses our analysis on how charter school entry and prevalence affects the school-level composition of students and teachers at TPS, for whom we have full information.

The school-level data files from NCERDC contain measures of school type (charter or traditional), school-level, student demographic characteristics, and exact school location. We restrict the sample to only urban and suburban schools. We do so because the relevant distance radius to examine charter sector growth will be different for rural areas, as will the patterns of charter school growth. Since our interest lies in the impact of charter competition along the intensive margin on TPS student and teacher sorting, we focus our analysis on urban and suburban schools where such competition is most directly relevant for influencing teacher and student behavior. We further restrict the sample to schools that contain at least one grade level between three and eight, corresponding to grades with End of Grade (EOG) testing requirements. ${ }^{5}$

$<<<$ Table 1 about here $>>>$

Table 1 provides summary statistics of student, teacher, and school characteristics separately by the type of school (TPS or charter) for all urban and suburban schools that meet

\footnotetext{
${ }^{5}$ We make this same restriction for TPS and charter schools. In our sample, $72 \%$ of charter schools contain both elementary school (K-5) grades and middle school (6-8) grades, $13 \%$ contain only elementary school grades, $8 \%$ contain only middle school grades, and $7 \%$ contain neither elementary nor middle school grades. The most common grade configuration by far is K-8. We therefore consider any charter school with a tested grade level as a viable teaching alternative to any TPS with a tested grade level. To the extent that this is not the case, our estimates of charter effects should be downward biased.
} 
our sample criteria previously outlined. Summarizing the schools in North Carolina shows that charters in North Carolina seem to be smaller (505 students on average versus 579 students) and have a higher proportion of students that are White than their TPS counterparts (49.9\% versus $43.2 \%)$. Teachers at charter schools that report teacher information have much higher turnover (43.6\% versus 30.0\%) and lower average levels of experience (10.8 versus 11.9 years). Notably, charter schools in North Carolina tend to open in more urban areas with higher median incomes and slightly lower rates of unemployment. As we detail in the following sections, this endogenous difference in charter siting motivates our identification strategy, as charters do not enter geographic areas at random and the endogenous demand for charters may be driven by factors unobserved to researchers that also affect TPS outcomes of interest, such as teacher recruitment and retention or student body composition.

\subsection{Measuring Charter Competition}

As noted previously, the influx of new charters after the cap removal often entered geographic areas with existing charters already in operation. Our main independent variable of interest will be the intensive margin of charter penetration in a given radius $r$ around a TPS. Conceptually, we are interested in charter schools that are sufficiently close to a traditional public school such that teachers and families may be tempted to move over to the charter school. For each traditional public school, we calculate the mileage distance to each charter school in each year. We can then calculate the nearby charter count as follows:

$$
\text { CharterCount }_{i t}=\sum_{j_{t}=1}^{J_{t}} \mathbb{1}\left(\text { Distance }_{i j_{t}} \leq r\right)
$$

In this formula, Distance $i j_{t}$ represents the geodesic distance from each traditional public school $i$ to each charter school open in that year $j_{t}=1, \ldots, J_{t}$. The charter count within that radius for TPS $i$ then becomes the sum of all charters for which the distance is less than a specified radius $r$. We experiment with several different thresholds for this maximum distance 
radius $r$. We prefer a 10 mile radius as it corresponds to average commuting distances in major North Carolina cities ${ }^{6}$, but have also replicated results with different thresholds for the maximum distance radius $r$ in Table A7.

Like prior research (Jackson, 2012), we also calculate an indicator variable to represent whether any charter exists within such a radius. However, we consider the within-radius count of schools defined above as equally important, since it captures the number of discrete options available to both teachers and families in a given community, and allows us to study how the number and types of options may have dynamic effects for both groups over time. For comparison, we also calculate the share of total student enrollment in a 10 mile radius enrolled at charter schools as an alternative measure of charter penetration.$^{7}$

As noted previously, the locations of charter school openings are not random and, as a result, TPS vary both in their likelihood of exposure to charter competition and in their existing student and teacher populations. We account for the non-random exposure to charter competition using the number of charter applications submitted within a given geographic radius of a TPS, interacted with the post-cap-removal period, as an instrument for the current number of nearby charter schools. To facilitate this approach, we collected data on all approved and not-approved charter school applications in the first year of the post-capremoval period from the North Carolina Department of Public Instruction, and geocoded their proposed locations $8^{8}$ There were a total of 91 applications, of which 33 were approved

\footnotetext{
${ }^{6} \mathrm{~A}$ recent report on commuting times showed average commuting distance in Charlotte as 9.7 miles and Raleigh as 8.5 miles (Kneebone and Holmes, 2015). As these are the two largest cities in the state, we interpret these distances as upper bound commutes, justifying a 10-mile radius for teachers working in urban and suburban areas in North Carolina. We also replicate these calculations, following the choices of Jackson (2012) and others, with a charter count within 2-mile radius and within 20-mile radius, with results available in Table A7. Gao and Semykina (2020) also show strong correlation between number of charters within 30 minutes travel time and number of charters within a 10 mile radius. Given the extent of exposure to at least one charter school within 20 miles before the cap removal, the sample is too small to estimate the effect of a charter entering a new area at the 20 mile radius after the cap removal. Similarly, very few TPS are exposed to multiple charters within 2 miles, even after the cap removal.

Table A6 presents the effects of changes in charter share of enrollment, using the preferred IV-DiD modeling approach. The results are strikingly similar to those in Table 3. We take the count of charter schools as our preferred measure of charter competition, for ease of interpretation and since the threshold of additional students before a new teaching position opens at a charter varies across charters. While a new charter school may enter at varying sizes, a new school is unlikely to enter with 0 teachers and 0 students.

${ }^{8}$ Most charter school applications mentioned a specific proposed school building site for which we could
} 
that year. Many others were approved in later years. The number of applications submitted in each particular geographic area can approximate the local endogenous demand for charter school services. We aggregate applications within each radius using the same approach as equation (1), but replace CharterCount ${ }_{i t}$ with ApplicationCount $_{i}$ for charter school applications submitted in 2012.

\subsection{Measuring Teacher Sorting and Characteristics}

The continuous entry of charter schools could in turn affect the quality of the local teacher workforce, many of whom would have otherwise continued (or started) working at traditional public schools. Such effects on the composition of teachers in TPS could be driven by changes in the selection mechanisms for teacher entry, changes in teachers switching between TPS and charter schools, or changes to teacher exit patterns. Because not all charter schools in North Carolina report information on their teachers during this time period, we are somewhat limited in our ability to disentangle these three different mechanisms.

We do measure, however, a school-level teacher turnover rate, new-to-teaching rate, and new-to-school rate, which can illuminate the question of how local charter school expansion affects teacher sorting in nearby public schools. For TPS $i$ in year $t$, we calculate the turnover rate as a function of teachers who have departed since the prior year TeachersLeaving ${ }_{i t-1}$ and the full sample of teachers in the prior year Teacher $s_{i t-1}:$ Turnover $_{i t}=\frac{\text { TeachersLeaving }_{i t-1}}{\text { Teachers }}$. $_{i t-1}$ This variable, which ranges from 0 to 1 , makes no restriction on why a teacher leaves the school, and makes no distinction between a teacher leaving the profession or just moving to a different school. As noted by Papay et al. (2017), counting teachers who leave a school temporarily and return in a later year in the turnover measure leads to misleadingly high turnover rates. Therefore, we exclude such temporary leavers from the turnover count. We

find the exact corresponding latitude and longitude. Some charter school applications did not have a specific proposed building site, and so we used the latitude and longitude of the school building that eventually opened. For charter school applications that were not approved, and that did not list a specific proposed building site, we used the center of the encompassing local school district as a proxy for the application location. This represented only a small number of cases. 
calculate the new-to-teaching rate as the proportion of teachers with zero experience in the

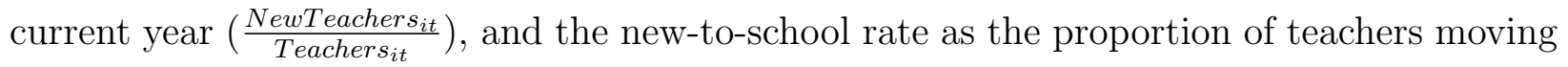
from a different $\mathrm{NC}$ school in the current year $\left(\frac{\text { MovetoSchool }_{i t}}{\text { Teachers }_{i t}}\right)$.

If charter expansion influences turnover of specific types of teachers from nearby public schools, or changes teacher recruitment patterns, then this could lead to aggregate changes in the characteristics of teachers at TPS. We test for this phenomenon using as dependent variables a variety of measures of teacher qualifications and effectiveness 99 The sample is restricted to instructors teaching in either math or English / Language Arts (ELA) classrooms in fourth through eighth grades each year, to allow for estimation of value-added measures.

We estimate teacher value-added (VA) scores by replicating the methods of Chetty et al. (2014). Because the step-by-step details of this method are provided in the appendix of their paper, we will merely summarize the major steps of this estimation process ${ }^{10}$ (i) Residualize student test scores with respect to controls and teacher fixed effects; (ii) Identify the teacher components of variance of residual test scores; and (iii) Construct teacher VA estimates using leave-year-out teacher mean scores to allow for drift over time. Teacher VA scores are calculated for reading and math separately.

Our second teacher characteristic measure is years of teaching experience. Because teachers generally become more effective across multiple dimensions as they gain experience (e.g., Ladd and Sorensen, 2017; Papay and Kraft, 2015; Wiswall, 2013), schools losing experienced teachers in response to charter entry may exhibit reduced instructional quality, and schools losing inexperienced teachers in response to charter entry may actually benefit in the short-term if they can find adequate replacement teachers.

\footnotetext{
${ }^{9}$ While generally, the effects of more intensive charter competition on teachers' salaries would be an important outcome to consider, in North Carolina, a statewide salary schedule compresses TPS teacher salaries and minimizes variation in teacher wages. While some districts do have merit bonuses available to teachers and, as Jackson (2012) shows, may use them in an effort to retain teachers in response to charter competition, such bonuses are also constrained in the amount available and the proportion of teachers that can be made eligible.

${ }^{10} \mathrm{We}$ use Michael Stepner's Stata module to complete this procedure, available at https://ideas.repec.org/c/boc/bocode/s457711.html. We residualize by teacher fixed effects and student race/ethnicity, gender, and lagged test score, and set the drift limit to 9.
} 
Our third teacher characteristic measure is an indicator of whether the teacher has a lateral or provisional license. Entering the teaching profession through lateral entry or with a temporary or provisional license is typically indicative of teachers with lower effectiveness in the classroom (Clotfelter et al., 2010; Henry et al., 2014). Therefore, particularly in the North Carolina context, this is a useful indicator of the quality and training of teachers.

And finally, our fourth teacher characteristic measure is an indicator of whether or not the teacher has attained a master's or doctoral degree. Once again, teachers entering the profession with a master's or other advanced degree have on average higher effectiveness in the classroom than those who don't, although these associations likely reflect teacher selection into advanced degrees rather than returns to the degree itself (Harris and Sass, 2011; Ladd and Sorensen, 2015). The extent to which increased prevalence of charter schools in an area affects the composition of teachers in traditional public schools has important policy and equity implications for the education sector.

\section{Methods}

We aim to identify the effect of charter schools entering a local education market on nearby TPS student and teacher characteristics. To do so, we consider both the first charter school to enter a geographic area (FirstCharter), and a continuous count of charter schools that enter the geographic area following the first charter (CharterCount) as different "treatments" to the TPS external environment. To identify effects of the first charter to open, we restrict the sample to only TPS that had no charter schools within the defined radius at the time of the cap removal. To identify the effects of subsequent charters, we restrict the sample to only TPS which had at least one charter school within the defined radius at the time of cap removal. We label these as, respectively, the extensive margin and intensive margin samples.

Due to the non-random location and timing of charter openings, we adopt and compare two empirical approaches. The first, Model 1, contains school and year fixed effects to control 
for time-invariant characteristics of the TPS as well as for any time trends that affect the full sample of North Carolina public schools. This model also adjusts for potential parallel trend violations by residualizing each outcome from its school-specific linear pretreatment time trend $\left(\right.$ year $\left._{t} \times \rho_{i}\right)$.

$$
\begin{array}{r}
Y_{i j t}=\alpha\left(\text { year }_{t} \times \rho_{i}\right)+\varepsilon_{i j t} \text { if } \text { year }_{t} \leq 2012 \\
Y_{i j t}^{R}=Y_{i j t}-\hat{\alpha}\left(\text { year }_{t} \times \rho_{i}\right) \\
Y_{i j t}^{R}=\beta \text { CharterCount }_{i j, t-1}+\varphi X_{j t}+\rho_{i}+\tau_{t}+\varepsilon_{i j t}
\end{array}
$$

In the equations above, $Y^{R}$ is the residualized teacher or student outcome, $X$ represents a vector of time varying characteristics (demographics, income, unemployment) of the counties $j$ around TPS that might influence charter demand, and $\rho_{i}$ and $\tau_{t}$ are school and year fixed effects. To estimate this model at the extensive margin, we simply replace the variable CharterCount with the indicator variable FirstCharter and change the sample of TPS to the extensive margin sample accordingly.

Model 2, our second and preferred method, is an instrumental variable difference-indifferences (IV-DiD) approach to account more fully for endogeneity in when and where charter schools open. The intuition behind the instrumental variable is as follows. We acknowledge that the demand for charter schools in a geographic area - measured through number of nearby charter applications (ApplicationCount) - is not random, and likely reflects underlying educational and community preferences or resources. Similarly, the timing of the charter cap removal (PostCap) could overlap with other changes happening in the state at the same time. However, the interaction between these two factors (ApplicationCount $\times$ PostCap), similar to a Treatment $\times$ Post interaction in a DiD model, allows us to capture the sudden growth in charter openings in some areas due to the cap removal.

In the first stage of two-stage least squares, we estimate the number of charters (CharterCount) nearby TPS $i$ in county $j$ during the prior year $(t-1)$ as a function of the charter cap removal 
timing and latent charter demand:

$$
\text { CharterCount }_{i j, t-1}=\vartheta\left(\text { ApplicationCount }_{i j, 2012} \times \text { PostCap }_{t}\right)+\varphi X_{j t}+\rho_{i}+\tau_{t}+\varepsilon_{i j t}
$$

We then estimate the second stage as the effect of each additional predicted charter school opening near a TPS on TPS teacher and student characteristics.

$$
Y_{i j t}=\beta \text { CharterC } \text { ount }_{i j, t-1}+\varphi X_{j t}+\rho_{i}+\tau_{t}+\varepsilon_{i j t}
$$

In equation (4), PostCap represents a binary indicator for post-cap-removal years 2013 through 2016 and ApplicationCount represents the number of charter applications submitted within the 10-mile radius of the TPS in 2012. The school fixed effect in this equation obviates the need to control for ApplicationCount directly, since that measure is time-invariant, and the year fixed effect similarly obviates the need to control for PostCap directly.

The identifying assumption of this approach is that, conditional on local latent demand for charters, local growth in charters following the cap removal independently affects TPS teacher and student behaviors. Under this assumption, $\beta$ in equation (5) represents the causal effect of each additional charter school on nearby TPS average teacher qualifications and student characteristics, accounting for school-specific effects, county characteristics, and year-specific effects. In the extensive margin version of this model, $\beta$ instead represents the causal effect of the first charter school opening.

Prior to 2012, the cap effectively constrained the supply of charters even in areas with high underlying demand. Figure 4 maps all charter schools that existed pre-cap-removal (light blue) and their proximity to TPS (grey). At the time of the legislative cap removal, the state received numerous applications proposing new charter schools (black). The map further indicates that charter schools that actually opened in years following the cap removal (red) tend to cluster around charter application sites, but the correspondence is certainly not one-to-one. Although charter openings frequently occurred in urban areas such as Charlotte, 
Greensboro, Durham, and Raleigh, TPS exposure to both charter demand and actual charter competition varied throughout the state.

$$
<<<\text { Figure } 4 \text { about here }>>>
$$

Finally, as noted in our descriptive analysis of the post-cap charter sector in North Carolina, many of the newly entering charters serve Whiter and more economically-advantaged student bodies. Thus, there may be heterogeneity in the impacts of charters conditional on the type of charter entering. Following Ladd et al. (2017), we examine the impact of entering charter schools in which White students make up $80 \%$ or more of the student body. Given the established teacher propensity to move to more advantaged schools as they gain experience (e.g., Feng, 2010; Clotfelter et al., 2006; Steele et al., 2015), charters within the same labor market serving predominantly White students might have particularly strong impacts on the recruitment and retention of teachers in TPS. We investigate possible heterogeneity of effects by adding the proportion of charter schools within 10 miles that are predominantly White as an endogenous variable to the model. We then instrument for both endogenous charter count and the share of charter schools serving predominantly White students using: (i) as before, the interaction of the number of charter applications with a post-cap removal indicator; and (ii) the original IV interacted with the proportion of county residents who are Black, Hispanic, and other race/ethnicity. As with Model 2 above, we estimate these effects of charter racial composition using two-stage least squares with school and year fixed effects and a series of county control variables.

\section{Results}

\subsection{Teacher sorting across TPS and charters}

Before directly estimating effects of charter growth on teacher labor markets, it is useful to understand the more general descriptive patterns of teacher sorting. To do so, we provide a 
direct comparison of teacher characteristics across groups of TPS teachers that either move to charters, move to other TPS, stay in their current TPS, or leave the NC public school system all together. Carruthers (2012b) explores this comparison in an earlier time period of data from North Carolina. She concludes that teachers moving to charter schools are less experienced, less likely to be licensed, less likely to hold graduate degrees, and less effective in terms of value-added scores than teachers who make similar shifts between traditional public schools. The first panel of Table 2 presents results for the pre-cap-removal time period and largely confirms the observations of Carruthers (2012b). It also shows that teachers from predominantly-White TPS are much less likely to move to charters than teachers from predominantly-nonWhite TPS.

$$
<<<\text { Table } 2 \text { about here }>>>
$$

The second panel presents a comparison of teachers during the post-cap-removal time period and indicates that sorting mechanisms have changed demonstrably. For example, movers to charters are no longer less effective in terms of value-added, and they are much less experienced and more credentialed on average than prior to the cap removal. Although the teacher data from charter schools underlying these comparative statistics is imperfect ${ }^{11}$, we believe these descriptive patterns suggest the presence of either nonlinear effects of charter sector growth on teacher sorting, or heterogeneous impacts of charter sector growth that vary by the characteristics of the new charter schools. We explore both potential mechanisms in detail.

\subsection{Impact of charter expansion on TPS teachers}

The rollout of charters among existing TPS may alter teachers' choices within the local labor market. As charters mature and more niche charters enter, the set of schools within a local

\footnotetext{
${ }^{11}$ In particular, the quality of reporting on teachers working in charter schools declines precipitously beginning in 2014, which both follows the rapid expansion of charters and corresponds to when DPI stopped collecting school activity report data. For this reason, we encourage readers to interpret the "movers to charter" column with caution.
} 
community may shift in terms of their student composition, working conditions, salary, and so on. For TPS, the coupling of expanded employment options and less stringent licensure requirements from nearby charters might lead to problems attracting and retaining novice teachers. It might also lead to either positive or negative selection of their current teachers who choose to depart for charter schools. Alternatively, charter and TPS teacher labor markets may develop entirely in parallel, with one having little influence on the other.

$$
<<\text { Table } 3 \text { about here }>>>
$$

We test these hypotheses by examining the effects of the charter cap removal on TPS teachers along extensive and intensive margins of exposure. Table 3 presents the estimated effect of additional charter competition after the cap removal on measures of teacher recruitment and retention, teachers credentials and effectiveness, and teacher diversity. We present both traditional difference-in-difference estimates using two-way fixed effects (TWFE) models detrended by pre-treatment school time trends and our preferred IV-DiD estimates. The top panel of Table 3 shows the effect of the first charter entering a 10 mile radius of a TPS after the cap removal in areas that had zero charters nearby before the cap was removed. The bottom panel presents the marginal effect of each additional charter in a 10 mile radius of a TPS in areas that had at least one charter nearby before the cap was removed. Corresponding first stage models are shown in Table A1.

First, regarding teacher recruitment and retention at TPS, our results suggest the charter cap removal had detrimental effects on recruitment of new teachers and modest effects on retention, and these effects primarily occur on the intensive margin of charter competition. For instance, while our TWFE estimates suggest charter entry reduces nearby TPS hires of rookie teachers by an average of 2 percentage-points, comparable to the effects documented by Jackson (2012), accounting for endogenous demand for charters makes the effect less precise and statistically indistinguishable from zero. This may be attributable to the smaller share of charters entering entirely new areas of the state after the cap removal 12 However,

\footnotetext{
${ }^{12}$ As Figure 4 shows, many charter applications and new charters after the cap removal appear near extant
} 
on the intensive margin, we see that each additional charter nearby reduces the proportion of new teachers at a TPS by 1.5 percentage points. While the impacts on the hiring of experienced teachers and the turnover rate are not statistically meaningful, average teacher experience increases with continued charter entry, evidence that suggests greater retention of existing teachers. The average TPS in our sample has 4 charter schools within 10 miles during the post-cap period. So, extrapolating from the marginal effects of a single additional charter opening, our results suggest that with the sample average entry of 4 nearby charters, TPS will experience a decline of new teachers from $5 \%$ of their workforce to $0 \%$, and a 1.2 year increase in average teacher experience.

Second, as teacher mobility patterns change so might the characteristics and qualifications of TPS teachers as the number of nearby charters grows. We look at average teacher valueadded scores and the proportion of teachers with a master's degree and provisional or lateral certification as measures of teacher quality. We also examine the effects on teacher diversity using the proportion of nonwhite teachers at a school. At the extensive margin, we find no effects of the first charter entry on teacher characteristics. At the intensive margin, while we find no evidence of overall effects on teacher value-added, we find positive effects on both the proportion of teachers with a master's degree and teacher diversity attributable to continuous charter entry. At the sample average of 4 nearby charters, the average TPS has a $17 \%$ increase in the proportion of teachers with a master's degree and a $12 \%$ increase in the proportion of nonwhite teachers at the school.

Collectively, these results illustrate that after the cap removal, continued charter entry into areas with existing charters had a significant impact on the mix of teachers. As the charter sector near a TPS expands, there appears to be a dual impact on the TPS teacher workforce. First, the less stringent licensing and educational requirements in charter schools appear to draw novice teachers from nearby TPS. Second, continued growth in the charter sector leads to a more diverse teacher workforce in TPS with higher credentials. Together, charter locations. 
the teacher sorting patterns we observe in North Carolina are consistent with the possibility that the charter sector serves as an early career training ground for teachers less certain about their long-run interest in a teaching career posited by Bruhn et al. (2020). They are also consistent with possible resource constraints imposed by charter school competition, whereby TPS are unable to hire as many new teachers. Finally, these results suggest that conventional TWFE estimates that do not account for latent endogenous demand for charters might understate the spillover effects of increased charter competition on the TPS teacher workforce.

$$
\begin{aligned}
& <<<\text { Figure 5 about here }>>> \\
& <<<\text { Figure 6 about here }>>>
\end{aligned}
$$

Of course, the type of charters entering might influence the nature of these compositional changes to teachers in the average urban and suburban TPS. It is possible that continued entry of "no-excuses" charters and charters aiming to serve predominantly Black or Hispanic students might have a different impact on a nearby TPS teacher workforce than entry of a charter catering to predominantly White students. For example, the effect of charter schools serving predominantly White students may have differential effects if teachers have racially biased preferences or if these charters have additional resources for attracting highly effective teachers. As previously described in the methods section, we investigate the effect of the entry of predominantly White charter schools using a similar IV-DiD identification strategy to estimate the effect of both the count of charters nearby and the share of additional charters that serve predominantly white students.

Figure 5 presents the estimated effect of a $100 \%$ increase in the share of nearby charters that serve predominantly White students following the cap removal ${ }^{13}$ The results show that

\footnotetext{
${ }^{13}$ See Table A4 for estimated coefficients. Although a 100 percentage point increase represents a large change, we do see many TPS with only predominantly-White or only predominantly-Nonwhite charter schools nearby due to racial segregation of schools. In our sample, 8.4 percent of TPS do experience a 100 percentage point increase in the proportion of charter schools nearby that are predominantly-White. Therefore readers can interpret these results as an upper bound of the effects of changing the racial composition of local charter schools.
} 
the marginal effect of additional charter competition on nearby TPS's teaching workforce differs by the type of charters entering the area. An increase in the share of new charters serving predominantly White student populations leads to the loss of more effective, more experienced, and better credentialed teachers at nearby TPS, holding constant overall charter competition. While the effects appear modest, they reflect changes in school-wide teacher averages - even small movements in such averages reflect practically substantial changes at a given school. In areas where all entering charters are predominantly White charter schools, nearby TPS experience a sizable loss of talented and experienced teachers.

Differentiating results by the racial composition of TPS illuminates these patterns further. Figure 6 again presents estimated effects on TPS teachers of increases in predominantlyWhite charters, now by TPS student composition. At TPS serving mostly Black, Hispanic, or other race students, increasing the share of nearby charters with mostly White students has a number of deleterious effects. It increases the rate of new teachers, reduces average teacher value-added, and reduces the proportion of teachers with master's degrees. These adverse effects are not observed, however, in TPS with mostly White students.14 For this second group of TPS, the only significant effects of increased predominantly-White charter share are a reduction in lateral entry and provisionally-licensed teachers and a reduction in teacher diversity.

Taken together, these findings show that the removal of a cap on charter schools has significantly altered the teaching workforce at nearby TPS by creating increased charter competition at the intensive margin. They further demonstrate that effects on the TPS teacher workforce vary by the type of TPS and type of charters opening nearby. Overall, increased charter competition reduces the inflow of novice teachers into TPS, and results in a TPS workforce of more experienced, credentialed, and diverse teachers, on average. However, the entry of charter schools serving predominantly White students has the reverse effect on teacher composition relative to other charters. In place of drawing less experienced

\footnotetext{
${ }^{14}$ The difference in effect sizes between predominantly-White and not-predominantly-White TPS is statistically significant for teacher value-added, teacher advanced degrees, and new-to-teaching rate.
} 
and less credentialed teachers away from TPS, charters with predominantly White students have negative effects on average TPS teacher effectiveness and qualifications.

\subsection{Impact of charter entry on student sorting}

To better understand the extent to which teacher choices are driven by or related to changes in student composition, we conclude our analysis by examining the impact of extensive and intensive charter entry on the student composition of TPS. On the one hand, growth in charters may divert students from TPS and lead to declining enrollments, loss of financial resources, and/or increased segregation along racial and economic lines. On the other, intensive charter entry may induce demand for residence in nearby school districts as parents feel they have additional options. We use the same identification strategy to estimate the effect of charter entry after the cap removal on TPS student populations and present both the TWFE and IV-DiD estimates in Table 4.

$$
<<<\text { Table } 4 \text { about here }>>>
$$

The top panel of Table 4 again shows the effect of a new charter in the post-cap period entering areas that previously did not have a charter nearby. The bottom panel estimates the effect of each additional charter entering after the cap removal. The results show that charter expansion on the extensive margin had little significant impact on nearby TPS student populations, other than a reduction in the pupil-to-teacher ratio of 1.8 students. While the point estimates suggest new charter entry may decrease the pupil-to-teacher ratio through reductions in nearby TPS enrollments, leaving a larger share of economically disadvantaged students at TPS, these effects are not statistically meaningful.

Meanwhile, each additional charter entering nearby at the intensive margin leads to an increase in nearby TPS enrollment of about 2 percentage-points and an increase in the pupilteacher ratio of about 0.3 students. This runs counter to our expectation that charter school openings would draw some students away from TPS, thereby lowering student enrollment. 
To further examine the mechanisms underlying this increase in TPS enrollment, we run a supplemental analysis of the effects of charter expansion on student movement across schools (Table A5). Although local charter expansion does significantly increase the number of TPS students moving to charters, these TPS also experience increased inflow of students in earlier grade levels and increased retention of students in middle school grade levels. This may be attributable to induced residential demand as a spillover of nearby charter openings, or as an artifact of parents keeping the option open of eventually transferring their child to a charter school. Because this enhanced recruitment and retention of students in the TPS is larger in magnitude than the loss of students to nearby charters, net student enrollment goes up.

Results from the traditional TWFE model in the bottom panel of Table 4 indicate that continued charter school entry leads to a TPS student population that is both Whiter and more economically-disadvantaged. Point estimates are similar or larger in the IV-DiD model, but not statistically significant. The rise in economically-disadvantaged students in TPS could reflect charter schools attracting higher-income students to switch from the public school system, a pattern consistent with the fact that charters overall in North Carolina serve far fewer economically-disadvantaged students than TPS (Table 1). Supplemental analyses to address whether the racial composition of charters affects the student population at nearby TPS, similar to Figure 5 and Figure 6, conclude that the opening of

predominantly-White charters similarly result in nearby TPS enrolling more White and economically-disadvantaged students (results available upon request). Overall, our findings imply that charter schools have not created enrollment problems for TPS, but they have prompted modest changes to the composition of students enrolled at TPS.

\subsection{Sensitivity tests}

We estimate several alternative models to test the robustness of our main findings. First, we note that entering charter schools may be of very different sizes, or may incrementally add grade levels, and therefore affect TPS teachers and students differently. An alternative 
measure to the charter count variable would be to calculate the share of total student enrollment within the 10 mile radius enrolled in charter schools. Table A6 shows that using charter share of student enrollment instead of the count of charter schools generates nearly identical results for teacher outcomes. Increasing the share of local enrollment in charter schools reduces the inflow of new teachers at TPS, increases average teacher experience, and increases the proportion of teachers with master's degrees.

Second, although the 10 mile radius is a reasonable geographic boundary for teacher labor markets based on prior research and commuting patterns (Jackson, 2012; Kneebone and Holmes, 2015), some teachers may respond only to charters opening very close to their current school, or they may respond to charters opening even farther from their current school than expected. Table A7 tests the sensitivity of our results to a 2 mile radius for first charter entry and to a 20 mile radius for continued charter entry ${ }^{15}$ Like the first charter entry in 10 miles of a TPS (Table 3), the first charter entry in 2 miles of a TPS has primarily null effects on teacher outcomes in the IV-DiD model. The only exception is that the first charter entry within 2 miles of a TPS leads to a large but marginally significant increase in the proportion of teachers at TPS that are lateral entry or provisionally-licensed. For continued entry of charters at the 20-mile intensive margin, we observe similar to the 10 mile radius significant reductions in new teachers, increases in average teacher experience, and increases in the proportion of teachers with master's degrees, though the coefficient magnitudes differ somewhat from our main results. Overall, these results confirm the same overarching effects of increased charter competition on TPS teachers, although each additional charter entering within 20 miles of the TPS has marginal effects slightly smaller in magnitude than each additional charter entering within 10 miles of the TPS.

Third, our main models assume that after the first nearby charter opens, all other nearby

\footnotetext{
${ }^{15}$ We cannot test the sensitivity of the extensive margin for a 20 mile radius because not enough TPS had no charters within a 20 mile radius at the time of cap removal, and we cannot test the sensitivity of the intensive margin for a 2 mile radius because not enough TPS had at least one charter within a 2 mile radius at the time of cap removal. The first stage F-statistics are also not large enough for reliable IV-DiD estimation of 2 miles for the intensive margin or 20 miles for the extensive margin (Table A1).
} 
charter openings affect TPS teachers and students in a linear fashion. This may not be the case if there are certain thresholds above which charter school competition has markedly larger (or smaller) effects. To explore such nonlinearities, we replace the simple charter count variable in the two-way fixed effects model with a series of indicator variables representing different numbers of charter schools within 10 miles: 0, 1, 2 to 3,4 to 6,7 to 9 , and 10 or more. Table A8 presents results from this approach for TPS teacher outcomes. For most outcomes, the coefficients illustrate a similar pattern to our main findings. For example, the number of new teachers entering the TPS decreases, average teacher experience and educational attainment increases, and the proportion of nonwhite teachers increases, in a relatively linear manner as the number of charters rises. Interestingly, we also observe that the first few charters opening nearby increase TPS teacher turnover, but that turnover returns to baseline levels as the number of nearby charters grows large. The proportion of teachers new-to-school, but not to teaching, also jumps higher after the first charter opening, and then flattens out. Overall, however, the findings in Table A8 suggest consistent patterns of change in the TPS teacher workforce in response to local charter expansion.

Finally, we note that particularly in the two-way fixed effects models, there may be unobservable factors associated with both increased charter competition and the outcome variables. Even in the IV-DiD model, it is possible that differential time-varying factors across TPS more and less affected by the charter cap removal could bias results. To better understand the approximate magnitude of unobservable selection, we test the stability of coefficient estimates by incrementally adding controls. In Table A9, we report results of the effects of the number of charters within 10 miles on the TPS teacher workforce from four models: (i) school fixed effects only; (ii) school fixed effects and control variables; (iii) school fixed effects and control variables, detrended by pre-treatment school time trends (Model 1); and (iv) the instrumental variables estimation (Model 2). Across all of the original significant outcomes - new teacher rate, new-to-school rate, average teacher experience, proportion of teachers with master's degrees, and proportion of teachers nonwhite - the 
coefficient estimates actually get larger as we add controls. This would suggest that, if unobservable confounders create bias in the same direction as observable confounders, our preferred estimates are actually conservative (Oster, 2019).

\section{Concluding Discussion}

An impressive body of research has examined how charter school openings shape the distribution of students and teachers across charters and traditional public schools. Some of this research has even focused specifically on the role of charter schools operating within the state of North Carolina (Bifulco and Ladd, 2007; Carruthers, 2012a, b; Jackson, 2012, Ladd et al., 2017). However, we show in this study that the size and nature of the charter sector has since changed fundamentally in response to a recent policy shift. The number of charters increased by $60 \%$ in the five years since this policy shift for which we have data. Moreover, the number of charters serving more racially-homogeneous student populations has continued to grow. The combination of these trends means that teachers and families selecting a school now face a variety of options within a given community, options previously unavailable.

Our analysis has documented how the composition and behaviors of teachers (and students) change as a result of this unprecedented expansion in charter schools. We find that, overall, intensive increases in charter competition reduced the inflow of new teachers at nearby TPS, leading to a more experienced workforce. The patterns we observe in North Carolina are consistent with the possibility that certification costs at TPS dissuade potentially interested teachers from entering the profession. This group of potential new teachers may instead enter through the charter sector wherein they can gain experience before incurring the costs of certification (Bruhn et al., 2020). Indeed, we find some evidence that each additional charter brings a modest increase in the share of newly hired teachers with prior teaching experience at nearby TPS. 
Although charter sector expansion leaves nearby TPS with a more experienced teaching workforce, surprisingly we find little evidence of improved average teacher effectiveness at TPS. One possibility is that some of the decline in new, inexperienced teachers at TPS can be attributed to recruitment difficulty or lost resources brought on by the increased entry of new charters nearby. That is, substituting experienced teachers from charters only partially offsets the decline in hiring new teachers and the gap reflects an unmet need for teachers for TPS. In our preferred IV-DiD estimates, we observe a continual increase in the pupil-teacher ratio in TPS as charters enter nearby, consistent with the possibility that at least some of the decline in new teacher entry at TPS represents unmet need for additional teachers. One possible explanation for the muted effect on average teacher effectiveness at TPS is that potential gains from a more experienced teaching workforce are offset by an increased average workload for each teacher.

On the student side, perhaps surprisingly, we find the intensive entry of charters increases nearby TPS enrollment by about 2-percentage points per charter. One potential explanation for enrollment growth at TPS is that nearby charter options make neighborhoods more attractive for a new set of parents. As we document in our supplemental analysis, while each additional charter increases the number of TPS students moving to charters, the number of students moving from outside the district in response to entering charters more than offsets the students lost to charters, particularly among younger students in elementary grade levels. Considering that North Carolina's year-to-year enrollment growth cap remained in place, though at a higher rate, after the charter school cap was removed, parents whose child was denied initial entry to a charter school under this enrollment cap may have nonetheless been enticed to move their child to a nearby TPS to keep open the option of transfer to the charter in later years. Alternatively, they may have been enticed more generally to the area by the robust availability of local schooling options, and perceived the new charter schools as some signal of neighborhood quality, even if they ultimately enrolled their child in a TPS. Of course, we cannot fully eliminate the possibility that our instrument, the number of charter 
applications at the time of cap removal interacted with the post-cap time period, violates the exclusion restriction assumption and does not fully account for endogenous student enrollment patterns.

Beyond total enrollments, when considering the effects of continuous charter entry on the composition of nearby TPS student populations, our preferred IV-DiD estimates were less precise than conventional DiD estimates but pointed toward nearby TPS students becoming Whiter and more economically disadvantaged. Given extant evidence that economically disadvantaged students are less likely to transfer to charters (Ni, 2012), these results are consistent with trends observed elsewhere. The intensive entry of nearby charter schools might lead to spillover increased enrollments at nearby TPS; however, as students sort into the new charters, a higher share of students remaining at the TPS will be economically disadvantaged.

Finally, we show that the new charters entering since the cap removal are frequently majority-economically-advantaged and majority-White. Following expansion of such predominantlyWhite charters, nearby TPS lose their more experienced and more qualified teachers, likely resulting in an increase in educational inequality for districts with this type of charter expansion. Traditional public schools that serve mostly Black and Hispanic students are most directly harmed by the influx of predominantly-White charters, as their average teacher value-added drops in reaction. These trends suggest that the early studies looking at noexcuses charter schools opening one or two at a time within metropolitan areas may soon be less relevant to the current education sector, particularly as more states ease their regulation of charter schools. Moreover, consistent with heterogeneity in charter schools' competitive effects on TPS performance observed in North Carolina along charter curricular dimensions Gilraine et al., 2020), our results suggest heterogeneous teacher labor market effects of charters on TPS along charter student body dimensions.

While our study of charter expansion provides a look at the impact on nearby TPS, our data limited our analysis in important respects that future researchers should revisit. North 
Carolina requires TPS to provide all personnel and student-level data needed for our analysis, but charter schools are exempted from such mandatory reporting. Although some charter schools report this information regardless, the proportion of charter schools that agree to share their information with North Carolina for research purposes varies across years and decreases noticeably following the policy change. Moreover, the charter schools that do consistently share their information likely vary in fundamental ways from the unobserved charters. Consequently, we cannot track teachers into many of the charter schools that enter in the post-reform period, nor can we answer important questions about the types of teachers charters recruit and the proportion that come from nearby TPS. Future researchers with teacher- and student-level data from all schools, including all charter schools, could build on our work in this direction. Finally, future research should consider the contribution of systematic differences between charters and TPS in working conditions, teacher autonomy, and school leadership to how teachers sort across schools (Grissom et al., 2016).

We also note that the policy intervention examined here, a charter cap removal paired with relaxation of regulations on charter schools, differs from recent cap removals in other states, such as Massachusetts. While Massachusetts provides some evidence that charter approaches to education can maintain efficacy at scale (Cohodes et al., 2019) and may incentivize shifting TPS resources toward instruction (Ridley and Terrier, 2018), the charter expansion in Massachusetts appears driven by expanding existing operators with a proven record of success, includes more substantial regulatory oversight over charters, and provide TPS with fiscal resources to mitigate the effects of an enrollment shock from charter expansion (Ridley and Terrier, 2018; Cohodes et al., 2019). North Carolina provides an opportunity to examine a similar rapid scale up of charter schools with fewer restrictions. While our identification allows for inference regarding the local average treatment effect of charter school openings following the cap removal in North Carolina, this broader, state-specific policy and operational context should be taken into account when interpreting the results of our study. Indeed, while nationally, charters generally serve relative few White students (Epple et al., 
2015), charters in North Carolina serve more White students and a relatively large share of the charter sector is made up of predominantly-White charter schools.

Our study looks at the unique intersection between state-level policy choices and the development of charter schools. Seemingly minor policy changes, such as removing a requirement that students in the charter represent the demographics of the population, can have major implications for the sorting of students and teachers over time. The removal of a cap on charters likewise had significant implications for the operation of traditional public schools, particularly in urban and suburban areas with high levels of charter expansion. Our results suggest that although the growth in the number and type of school options in a concentrated area caries the benefit of choice for individual families and teachers alike, the collective outcome might be lasting challenges for the recruitment and retention of qualified teachers at nearby TPS. 


\section{References}

Abdulkadiroglu, A., Angrist, J. D., Cohodes, S., Dynarski, S., Fullerton, J., Kane, T. J., and Pathak, P. (2009). Informing the Debate: Comparing Boston's Charter, Pilot and Traditional Schools. Technical Report January, The Boston Foundation, Boston, MA.

Abdulkadiroğlu, A. and Sönmez, T. (2003). School choice: A mechanism design approach. American Economic Review, 93(3):729-747.

Abdulkadiroğlu, A., Angrist, J. D., Dynarski, S. M., Kane, T. J., and Pathak, P. A. (2011). Accountability and flexibility in public schools: Evidence from boston's charters and pilots. Quarterly Journal of Economics, 126(2):699-748.

Angrist, J., Bettinger, E., Bloom, E., King, E., and Kremer, M. (2002). Vouchers for private schooling in colombia: Evidence from a randomized natural experiment. American economic review, 92(5):1535-1558.

Angrist, J. D., Dynarski, S. M., Kane, T. J., Pathak, P. A., and Walters, C. R. (2010). Inputs and impacts in charter schools: Kipp lynn. American Economic Review, 100(2):239-43.

Arsen, D. and Ni, Y. (2012). The effects of charter school competition on school district resource allocation. Educational Administration Quarterly, 48(1):3-38.

Berends, M. (2015). Sociology and School Choice: What We Know After Two Decades of Charter Schools. Annual Review of Sociology, 41(1):150504162558008.

Bergman, P. and McFarlin Jr, I. (2018). Education for all? a nationwide audit study of school choice. Technical report, National Bureau of Economic Research.

Betts, J. R. and Tang, Y. E. (2014). A meta-analysis of the literature on the effect of charter schools on student achievement. Society for Research on Educational Effectiveness.

Bifulco, R. and Ladd, H. F. (2006). The Impacts of Charter Schools on Student Achievement: Evidence from North Carolina. Education Finance and Policy, 1(1):50-90.

Bifulco, R. and Ladd, H. F. (2007). School choice, racial segregation, and test-score gaps: Evidence from north carolina's charter school program. Journal of Policy Analysis and Management, 26(1):31-56.

Bifulco, R. and Reback, R. (2014). Fiscal impacts of charter schools: lessons from new york. Education Finance and Policy, 9(1):86-107.

Booker, K., Gilpatric, S. M., Gronberg, T., and Jansen, D. (2008). The effect of charter schools on traditional public school students in Texas: Are children who stay behind left behind? Journal of Urban Economics, 64(1):123-145.

Boyd, D., Grossman, P., Lankford, H., Loeb, S., and Wyckoff, J. (2006). How changes in entry requirements alter the teacher workforce and affect student achievement. Education Finance and Policy, 1(2):176-216.

Boyd, D., Grossman, P. L., Hammerness, K., Lankford, R. H., Loeb, S., McDonald, M., Reininger, M., Ronfeldt, M., and Wyckoff, J. (2008). Surveying the Landscape of Teacher Education in New York City: Constrained Variation and the Challenge of Innovation. Educational Evaluation and Policy Analysis, 30(4):319-343.

Bruhn, J., Imberman, S. A., and Winters, M. A. (2020). Regulatory arbitrage in teacher hiring and retention: Evidence from massachusetts charter schools. NBER Working Paper, (w27607).

Buckley, J. and Schneider, M. (2005). Are Charter School Students Harder to Educate? Evidence From Washington, D.C. Educational Evaluation and Policy Analysis, 27(4):365- 
380.

Carruthers, C. K. (2012a). New schools, new students, new teachers: Evaluating the effectiveness of charter schools. Economics of Education Review, 31(2):280-292.

Carruthers, C. K. (2012b). The qualifications and classroom performance of teachers moving to charter schools. Education Finance and Policy, 7(3):233-268.

Carver-Thomas, D. and Darling-Hammond, L. (2017). Why black women teachers leave and what can be done about it. In Black female teachers: Diversifying the United States' teacher workforce, pages 159-184. Emerald Publishing Limited.

Cheng, A., Hitt, C., Kisida, B., and Mills, J. N. (2017). "no excuses" charter schools: A meta-analysis of the experimental evidence on student achievement. Journal of School Choice, 11(2):209-238.

Chetty, R., Friedman, J. N., and Rockoff, J. E. (2014). Measuring the Impacts of Teachers I: Evaluating Bias in Teacher Value-Added Estimates. American Economic Review, 104(9):2593-2632.

Clark, M. A., Gleason, P. M., Tuttle, C. C., and Silverberg, M. K. (2015). Do Charter Schools Improve Student Achievement? Educational Evaluation and Policy Analysis, 37(4):419-436.

Clotfelter, C., Ladd, H. F., Vigdor, J., and Wheeler, J. (2006). High-poverty schools and the distribution of teachers and principals. NCL Rev., 85:1345.

Clotfelter, C. T., Ladd, H. F., and Vigdor, J. (2005). Who teaches whom? race and the distribution of novice teachers. Economics of Education review, 24(4):377-392.

Clotfelter, C. T., Ladd, H. F., and Vigdor, J. L. (2010). Teacher Credentials and Student Achievement in High School: A Cross-Subject Analysis with Student Fixed Effects. Journal of Human Resources, 45(3):655-681.

Cohodes, S. (2018). Charter schools and the achievement gap. The Future of Children, pages $1-16$.

Cohodes, S., Setren, E., and Walters, C. R. (2019). Can successful schools replicate? scaling up boston's charter school sector. Technical report, National Bureau of Economic Research.

Cook, J. B. (2018). The effect of charter competition on unionized district revenues and resource allocation. Journal of Public Economics, 158:48-62.

Cremata, E., Davis, D., Dickey, K., Lawyer, K., Negassi, Y., Raymond, M. E., and Woodworth, J. L. (2013). National Charter School Study. Technical report, Center for Research on Education Outcomes (CREDO), Stanford, CA.

Dee, T. S. (2005). A teacher like me: Does race, ethnicity, or gender matter? American Economic Review, 95(2):158-165.

Dee, T. S. and Fu, H. (2004). Do charter schools skim students or drain resources? Economics of Education Review, 23(3):259-271.

Dobbie, W. and Fryer, R. G. J. (2011). Are High-Quality Schools Enough to Increase Achievement Among the Poor? Evidence from the Harlem Children's Zone. American Economic Journal: Applied Economics, 3(3):158-187.

Epple, D., Romano, R., and Zimmer, R. (2015). Charter schools: A survey of research on their characteristics and effectiveness. Working Paper 21256, National Bureau of Economic Research.

Feng, L. (2010). Hire today, gone tomorrow: New teacher classroom assignments and teacher 
mobility. Education Finance and Policy, 5(3):278-316.

Friedman, M. (1997). Public schools: Make them private. Education Economics, 5(3):341344.

Gao, N. and Semykina, A. (2020). Competition effects of charter schools: New evidence from north carolina. Journal of School Choice, pages 1-24.

Gershenson, S., Hart, C., Hyman, J., Lindsay, C., and Papageorge, N. W. (2018). The long-run impacts of same-race teachers. Technical Report w25254, National Bureau of Economic Research.

Gershenson, S., Holt, S. B., and Papageorge, N. W. (2016). Who believes in me? the effect of student-teacher demographic match on teacher expectations. Economics of Education Review, 52:209-224.

Gilraine, M., Petronijevic, U., and Singleton, J. D. (2020). Horizontal differentiation and the policy effect of charter schools. American Economic Journal: Economic Policy, X(X):1-76.

Glazerman, S., Max, J., et al. (2011). Do low-income students have equal access to the highest-performing teachers? Technical report, Mathematica Policy Research.

Gleason, P. M. (2019). Let the search continue: charter schools and the public interest. Journal of Policy Analysis and Management, 38(4):1054-1062.

Gleason, P. M., Clark, M. a., Tuttle, C. C., and Dwoyer, E. (2010). The Evaluation of Charter School Impacts Final Report. Technical report, U.S. Department of Education, Washington, D.C.

Grissom, J. A., Viano, S. L., and Selin, J. L. (2016). Understanding employee turnover in the public sector: Insights from research on teacher mobility. Public Administration Review, 76(2):241-251.

Hanushek, E. A., Kain, J. F., and Rivkin, S. G. (2004). Why public schools lose teachers. Journal of Human Resources, 39(2):326-354.

Hanushek, E. A. and Rivkin, S. G. (2006). Teacher quality. Handbook of the Economics of Education, 2:1051-1078.

Harris, D. N. and Sass, T. R. (2011). Teacher training, teacher quality and student achievement. Journal of public economics, 95(7-8):798-812.

Henry, G. T., Purtell, K. M., Bastian, K. C., Fortner, C. K., Thompson, C. L., Campbell, S. L., and Patterson, K. M. (2014). The Effects of Teacher Entry Portals on Student Achievement. Journal of Teacher Education, 65(1):7-23.

Holt, S. B. and Gershenson, S. (2017). The impact of demographic representation on absences and suspensions. Policy Studies Journal.

Hoxby, C. M. (2003). Could School Choice Be a Tide that Lifts All Boats? In Hoxby, C. M., editor, The Economics of School Choice, number January in 1, chapter 8, pages 287-341. University of Chicago Press, Chicago, IL.

Hoxby, C. M., Murarka, S., and Kang, J. (2009). How new york city's charter schools affect achievement, august 2009 report. Technical Report September, New York City Charter Schools Evaluation Project, Cambridge, MA.

Hoxby, C. M. and Rockoff, J. E. (2005). The impact of charter schools on student achievement.

Imberman, S. A. (2011). The effect of charter schools on achievement and behavior of public school students. Journal of Public Economics, 95(7-8):850-863.

Isenberg, E., Max, J., Gleason, P., Johnson, M., Deutsch, J., and Hansen, M. (2016). Do 
low-income students have equal access to effective teachers. Mathematica Policy Research, 26.

Jackson, C. K. (2009). Student Demographics, Teacher Sorting, and Teacher Quality: Evidence from the End of School Desegregation. Journal of Labor Economics, 27(2):213-256.

Jackson, C. K. (2012). School competition and teacher labor markets: Evidence from charter school entry in North Carolina. Journal of Public Economics, 96(5-6):431-448.

Kneebone, E. and Holmes, N. (2015). The growing distance between people and jobs in metropolitan america. Technical report, Brookings Institute.

Lacireno-Paquet, N., Holyoke, T. T., Moser, M., and Henig, J. R. (2002). Creaming versus Cropping: Charter School Enrollment Practices in Response to Market Incentives. Educational Evaluation and Policy Analysis, 24(2):145-158.

Ladd, H. F. (2019). How charter schools threaten the public interest. Journal of Policy Analysis and Management, 38(4):1063-1071.

Ladd, H. F., Clotfelter, C. T., and Holbein, J. B. (2017). The growing segmentation of the charter school sector in North Carolina. Education Finance and Policy, 12(4):536-563.

Ladd, H. F. and Singleton, J. D. (2017). The fiscal externalities of charter schools: Evidence from north carolina. Education Finance and Policy, pages 1-34.

Ladd, H. F. and Sorensen, L. C. (2015). Do master's degrees matter? advanced degrees, career paths, and the effectiveness of teachers. working paper 136. National Center for Analysis of Longitudinal Data in Education Research (CALDER).

Ladd, H. F. and Sorensen, L. C. (2017). Returns to teacher experience: Student achievement and motivation in middle school. Education Finance and Policy, 12(2):241-279.

Mansfield, R. K. (2015). Teacher quality and student inequality. Journal of Labor Economics, 33(3):751-788.

Marcotte, D. E. and Dalane, K. (2019). Socioeconomic segregation and school choice in american public schools. Educational Researcher, 48(8):493-503.

McCraw, K., Chauhan, D., and Counsels, C. (2011). Senate pcs 8: No cap on number of charter schools. Technical report, North Carolina State Board of Education, Department of Public Instruction.

McCraw, K., Chauhan, D., and Counsels, C. (2016). Senate pcs 8: No cap on number of charter schools. Technical report, North Carolina State Board of Education, Department of Public Instruction.

Ni, Y. (2009). The impact of charter schools on the efficiency of traditional public schools: Evidence from Michigan. Economics of Education Review, 28(5):571-584.

Ni, Y. (2012). The sorting effect of charter schools on student composition in traditional public schools. Educational Policy, 26(2):215-242.

Oster, E. (2019). Unobservable selection and coefficient stability: Theory and evidence. Journal of Business \& Economic Statistics, 37(2):187-204.

Papay, J. P., Bacher-Hicks, A., Page, L. C., and Marinell, W. H. (2017). The challenge of teacher retention in urban schools: Evidence of variation from a cross-site analysis. Educational Researcher, 46(8):434-448.

Papay, J. P. and Kraft, M. A. (2015). Productivity returns to experience in the teacher labor market: Methodological challenges and new evidence on long-term career improvement. Journal of Public Economics, 130:105-119.

Putman, H., Hansen, M., Walsh, K., and Quintero, D. (2016). High hopes and harsh realities: 
The real challenges to building a diverse workforce. Brookings Institution.

Ridley, M. and Terrier, C. (2018). Fiscal and education spillovers from charter school expansion. Technical report, National Bureau of Economic Research.

Sass, T. R. (2006). Charter schools and student achievement in florida. Education Finance and Policy, 1(1):91-122.

Sass, T. R., Hannaway, J., Xu, Z., Figlio, D. N., and Feng, L. (2012). Value added of teachers in high-poverty schools and lower poverty schools. Journal of Urban Economics, $72(2-3): 104-122$.

Steele, J. L., Pepper, M. J., Springer, M. G., and Lockwood, J. R. (2015). The distribution and mobility of effective teachers: Evidence from a large, urban school district. Economics of Education Review, 48:86-101.

Tuttle, C. C., Gleason, P., and Clark, M. (2012). Using lotteries to evaluate schools of choice: Evidence from a national study of charter schools. Economics of Education Review, $31(2): 237-253$.

Vinopal, K. and Holt, S. B. (2019). Rookie mistakes: The interplay of teacher experience and racial representation. Educational Researcher, 48(7):421-437.

Winters, M. A. (2012). Measuring the effect of charter schools on public school student achievement in an urban environment: Evidence from New York City. Economics of Education Review, 31(2):293-301.

Winters, M. A. (2015). Understanding the Gap in Special Education Enrollments Between Charter and Traditional Public Schools: Evidence From Denver, Colorado. Educational Researcher, 44(4):228-236.

Winters, M. A., Clayton, G., and Carpenter, D. M. (2017). Are low-performing students more likely to exit charter schools? Evidence from New York City and Denver, Colorado. Economics of Education Review, 56:110-117.

Wiswall, M. (2013). The dynamics of teacher quality. Journal of Public Economics, 100:6178.

Zimmer, R. and Buddin, R. (2009). Is charter school competition in California improving the performance of traditional public schools? Public Administration Review, 69(5):831-845.

Zimmer, R., Gill, B., Booker, K., Lavertu, S., and Sass, T. R. (2009). Charter schools in eight states: Effects on achievement, attainment, integration, and competition. Rand Corporation.

Zimmer, R., Gill, B., Booker, K., Lavertu, S., and Witte, J. (2012). Examining charter student achievement effects across seven states. Economics of Education Review, 31(2):213224.

Zimmer, R. W. and Guarino, C. M. (2013). Is There Empirical Evidence That Charter Schools "Push Out" Low-Performing Students? Educational Evaluation and Policy Analysis, 35(4):461-480. 


\section{Tables and Figures}

Figure 1: Number of Charter Schools in North Carolina 2006-2016

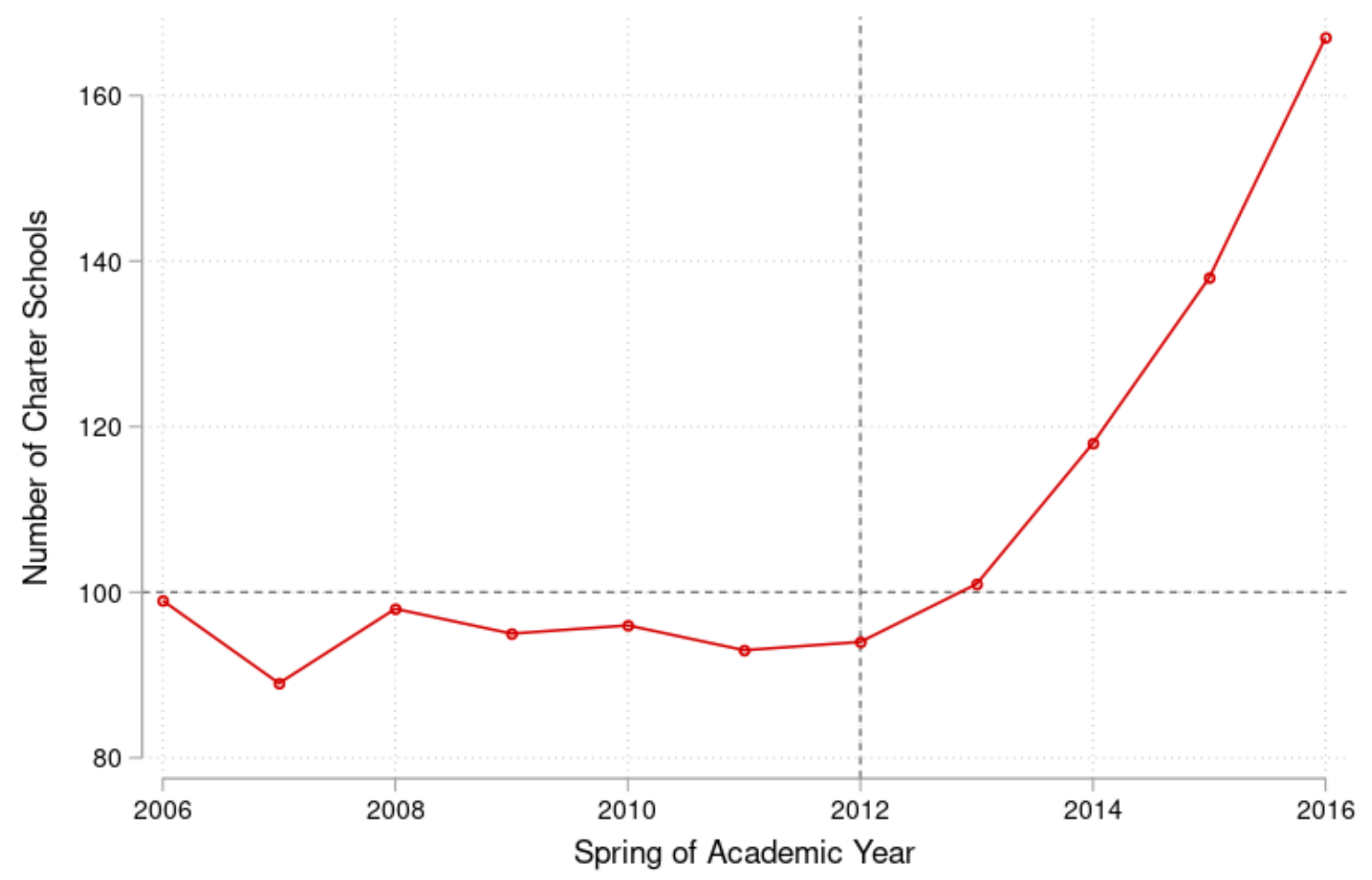

Note. The number of charter schools in the state was capped at 100 prior to removal of the cap in 2012 . The cap is signified by a horizontal dashed line. 
Figure 2: Number of Charters in 10 Mile Radius of TPS Before and After Cap Removal

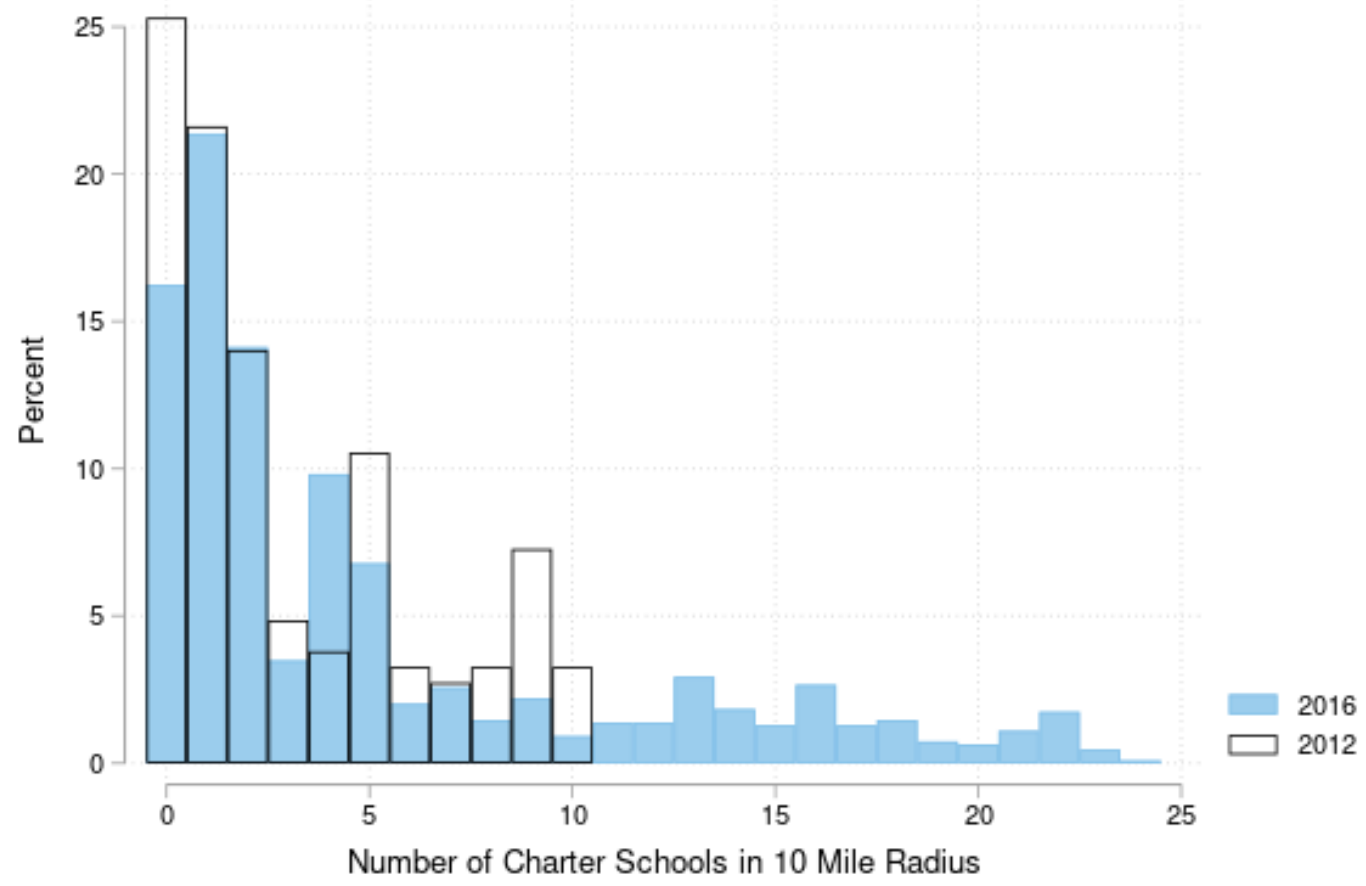

Note. This graph is two overlapping histogram plots, showing the percent of traditional public schools with each number of charter schools within a 10 mile radius in 2012, as compared to in 2016. 
Figure 3: Number of Charter Schools by Racial Composition 2006-2016

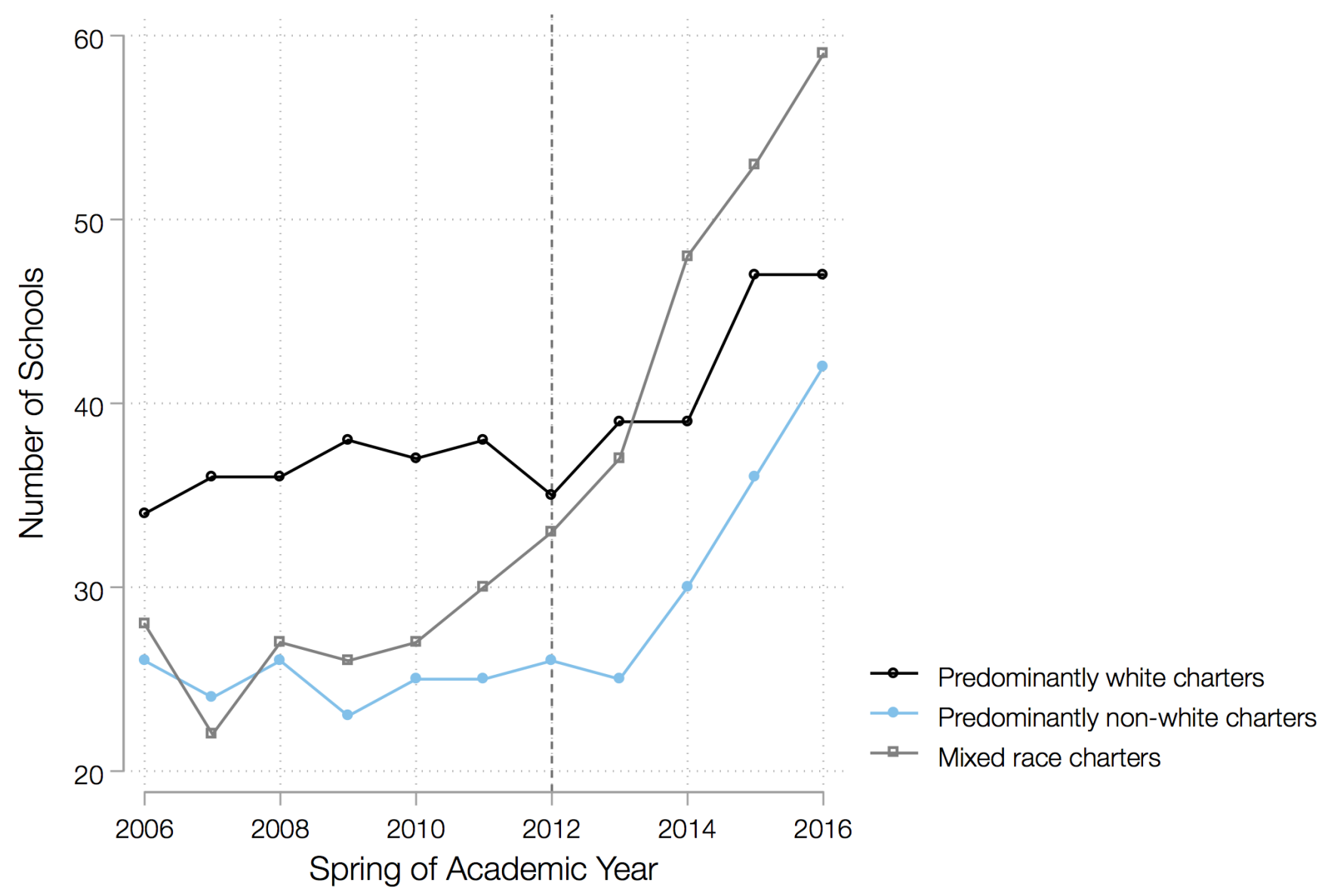

Note. The removal of the charter cap in 2012 is signified by a vertical dashed line. Predominantly white charters have greater than $80 \%$ white students, predominantly nonwhite charters have less than $20 \%$ white, and mixed race charters have any other student racial composition. 
Figure 4: Geography of Charter School Applications and Growth After Cap Removal

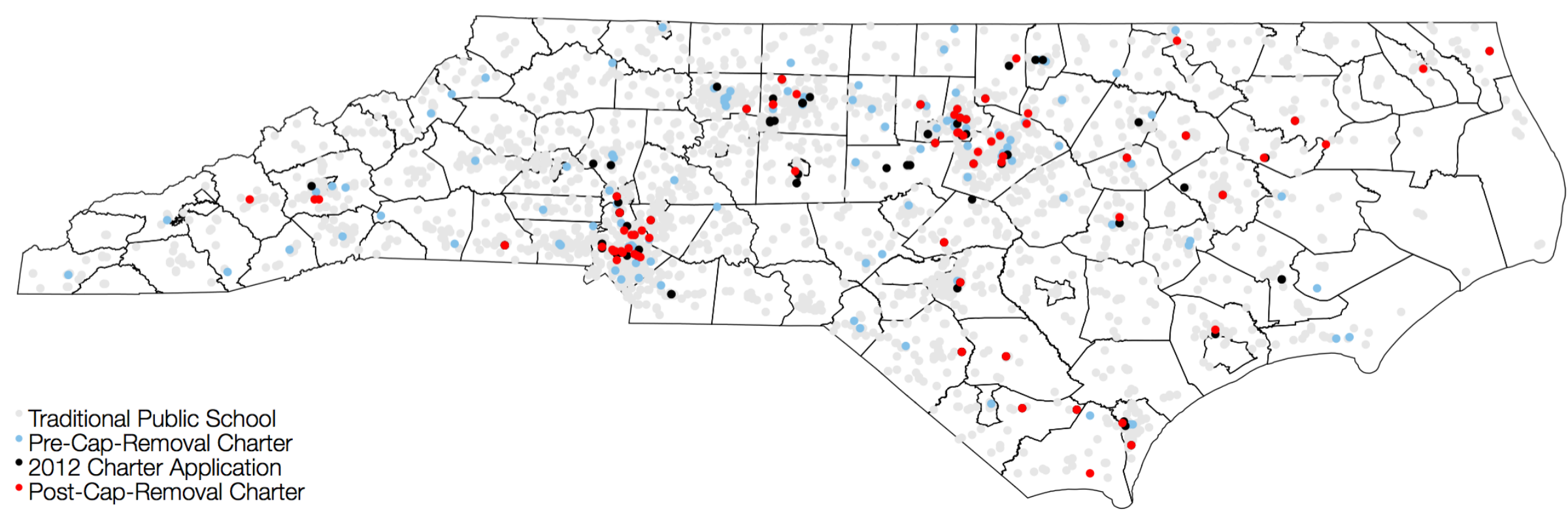

Note. Each light grey dot represents a traditional public school in our sample at any time between 2007 and 2016. Each light blue dot is a charter school operating in the state anytime between 2007 and 2012; each black dot represents the proposed location of a charter school in one of the charter school applications for the 2012 school year; and each red dot is a charter school that opened post-2012. 
Table 1: Descriptive Statistics by School Type

\begin{tabular}{|c|c|c|}
\hline & $\begin{array}{c}(1) \\
\text { TPS Sample }\end{array}$ & $\begin{array}{c}(2) \\
\text { Charter Sample }\end{array}$ \\
\hline Elementary school & $\begin{array}{c}0.655 \\
(0.475)\end{array}$ & $\begin{array}{c}0.132^{* * * *} \\
(0.339)\end{array}$ \\
\hline Middle school & $\begin{array}{c}0.253 \\
(0.435)\end{array}$ & $\begin{array}{c}0.076^{* * *} \\
(0.265)\end{array}$ \\
\hline Other grade range & $\begin{array}{c}0.092 \\
(0.288)\end{array}$ & $\begin{array}{c}0.792^{* * *} \\
(0.406)\end{array}$ \\
\hline Located in city & $\begin{array}{c}0.456 \\
(0.498)\end{array}$ & $\begin{array}{c}0.567^{* * *} \\
(0.496)\end{array}$ \\
\hline Located in suburb or town & $\begin{array}{c}0.295 \\
(0.456)\end{array}$ & $\begin{array}{c}0.193^{* * *} \\
(0.395)\end{array}$ \\
\hline New to teaching (\%) & $\begin{array}{c}4.444 \\
(7.689)\end{array}$ & $\begin{array}{l}1.369^{* * *} * \\
(10.900)\end{array}$ \\
\hline New to school $(\%)$ & $\begin{array}{c}7.817 \\
(12.156)\end{array}$ & $\begin{array}{c}14.984^{* * * *} \\
(27.217)\end{array}$ \\
\hline Teacher departure (\%) & $\begin{array}{c}29.963 \\
(20.521)\end{array}$ & $\begin{array}{c}43.660^{* * *} \\
(36.977)\end{array}$ \\
\hline Average teacher value-added & $\begin{array}{c}0.011 \\
(0.092)\end{array}$ & $\begin{array}{c}0.006 \\
(0.100)\end{array}$ \\
\hline Average teacher experience & $\begin{array}{l}11.851 \\
(4.235)\end{array}$ & $\begin{array}{c}10.789 * * * \\
(8.279)\end{array}$ \\
\hline Percent of teachers lateral/provisional & $\begin{array}{c}5.979 \\
(10.077)\end{array}$ & $\begin{array}{c}5.934 \\
(18.605)\end{array}$ \\
\hline Percent of teachers advanced degree & $\begin{array}{c}35.054 \\
(20.209)\end{array}$ & $\begin{array}{c}42.191^{* * * *} \\
(46.205)\end{array}$ \\
\hline Percent of teachers non-White & $\begin{array}{c}21.338 \\
(23.757)\end{array}$ & $\begin{array}{c}29.776^{* * * *} \\
(37.658)\end{array}$ \\
\hline Total student enrollment & $\begin{array}{c}578.949 \\
(268.632)\end{array}$ & $\begin{array}{c}505.067^{* * *} \\
(372.585)\end{array}$ \\
\hline Full-time-equivalent teachers & $\begin{array}{c}39.056 \\
(15.117)\end{array}$ & $\begin{array}{c}32.088^{* * * *} \\
(22.821)\end{array}$ \\
\hline Percent of students White & $\begin{array}{c}43.233 \\
(26.566)\end{array}$ & $\begin{array}{c}49.880^{* * *} \\
(36.246)\end{array}$ \\
\hline Percent of students Black & $\begin{array}{c}34.106 \\
(24.178)\end{array}$ & $\begin{array}{c}36.907^{* *} \\
(35.459)\end{array}$ \\
\hline Percent students Hispanic & $\begin{array}{c}15.340 \\
(12.788)\end{array}$ & $\begin{array}{c}6.579^{* * *} \\
(9.063)\end{array}$ \\
\hline Percent students other race & $\begin{array}{c}5.473 \\
(7.801)\end{array}$ & $\begin{array}{c}5.973 \\
(13.378)\end{array}$ \\
\hline Percent students economic disadvantage & $\begin{array}{c}59.974 \\
(43.360)\end{array}$ & $\begin{array}{c}38.807 * * * \\
(34.544)\end{array}$ \\
\hline County unemployment rate & $\begin{array}{l}7.743 \\
(2.601)\end{array}$ & $\begin{array}{l}7.527^{*} \\
(2.501)\end{array}$ \\
\hline County median income & $\begin{array}{l}58980.924 \\
(9843.132) \\
\end{array}$ & $\begin{array}{c}61690.511^{* * *} \\
(10737.609)\end{array}$ \\
\hline Observations & 9447 & 554 \\
\hline
\end{tabular}

Means with standard deviations in parentheses; the sample includes schools with tested grades (3-8) in urban/suburban areas. The mean differences between TPS and charter samples are tested with t-tests for continuous variables and Pearson's chi-squared tests for binary variables.

$* \mathrm{p}<.10^{* *} \mathrm{p}<.05 * * * \mathrm{p}<.01$. 
Table 2: Comparison of Movers, Stayers, and Leavers by Time Period

\begin{tabular}{|c|c|c|c|c|}
\hline Characteristics & $\begin{array}{c}(1) \\
\text { Mover } \\
\text { (To Charter) }\end{array}$ & $\begin{array}{c}(2) \\
\text { Mover } \\
\text { (To Other TPS) }\end{array}$ & $\begin{array}{c}(3) \\
\text { Stayer } \\
\text { (At TPS) }\end{array}$ & $\begin{array}{c}(4) \\
\text { Leaver } \\
\text { (At Neither) }\end{array}$ \\
\hline \multicolumn{5}{|c|}{ Pre-Removal of Charter Cap } \\
\hline Value-Added (SDs) & $\begin{array}{c}-0.037^{\mathbf{B}} \\
(0.143)\end{array}$ & $\begin{array}{c}-0.003^{\mathbf{A}, \mathbf{B}} \\
(0.153)\end{array}$ & $\begin{array}{c}-0.001^{\mathbf{A}, \mathbf{B}} \\
(0.153)\end{array}$ & $\begin{array}{c}-0.022^{\mathbf{B}} \\
(0.141)\end{array}$ \\
\hline Years of Experience & $\begin{array}{c}10.339 \\
(10.084)\end{array}$ & $\begin{array}{c}11.686^{\mathbf{B}} \\
(8.970)\end{array}$ & $\begin{array}{c}11.859^{\mathrm{B}} \\
(8.987)\end{array}$ & $\begin{array}{c}12.207^{\mathbf{A}, \mathbf{B}} \\
(10.364)\end{array}$ \\
\hline Lateral/Provisional License & $\begin{array}{l}0.148^{\mathbf{B}} \\
(0.356)\end{array}$ & $\begin{array}{c}0.066^{\mathbf{A}, \mathbf{B}} \\
(0.249)\end{array}$ & $\begin{array}{c}0.065^{\mathbf{A}, \mathbf{B}} \\
(0.246)\end{array}$ & $\begin{array}{c}0.078^{\mathbf{A}, \mathbf{B}} \\
(0.268)\end{array}$ \\
\hline Advanced Degree & $\begin{array}{c}0.273 \\
(0.447)\end{array}$ & $\begin{array}{l}0.303^{\mathrm{B}} \\
(0.459)\end{array}$ & $\begin{array}{l}0.304^{\mathrm{B}} \\
(0.460)\end{array}$ & $\begin{array}{l}0.332^{\mathrm{B}} \\
(0.471)\end{array}$ \\
\hline Teacher Nonwhite & $\begin{array}{c}0.189 \\
(0.393)\end{array}$ & $\begin{array}{l}0.172^{\mathrm{B}} \\
(0.378)\end{array}$ & $\begin{array}{l}0.170^{\mathrm{B}} \\
(0.375)\end{array}$ & $\begin{array}{l}0.211^{\mathrm{B}} \\
(0.408)\end{array}$ \\
\hline TPS Students Predominantly White & $\begin{array}{c}0.383 \\
(0.488)\end{array}$ & $\begin{array}{c}0.579^{\mathbf{A}, \mathbf{B}} \\
(0.494)\end{array}$ & $\begin{array}{c}0.588^{\mathbf{A}, \mathbf{B}} \\
(0.492)\end{array}$ & $\begin{array}{c}0.517^{\mathbf{A}, \mathbf{B}} \\
(0.500)\end{array}$ \\
\hline Observations & 149 & 78,596 & 72,941 & 28,319 \\
\hline \multicolumn{5}{|c|}{ Post-Removal of Charter Cap } \\
\hline Value-Added (SDs) & $\begin{array}{c}0.002 \\
(0.119)\end{array}$ & $\begin{array}{l}0.027^{\mathbf{A}} \\
(0.138)\end{array}$ & $\begin{array}{c}0.029^{\mathbf{A}} \\
(0.138)\end{array}$ & $\begin{array}{l}-0.002 \\
(0.124)\end{array}$ \\
\hline Years of Experience & $\begin{array}{c}8.569 \\
(6.710)\end{array}$ & $\begin{array}{c}11.985^{\mathbf{A}} \\
(8.281)\end{array}$ & $\begin{array}{c}12.216^{\mathbf{A}} \\
(8.319)\end{array}$ & $\begin{array}{c}11.769^{\mathbf{A}} \\
(9.392)\end{array}$ \\
\hline Lateral/Provisional License & $\begin{array}{c}0.068 \\
(0.252)\end{array}$ & $\begin{array}{c}0.049 \\
(0.217)\end{array}$ & $\begin{array}{c}0.048 \\
(0.214)\end{array}$ & $\begin{array}{c}0.062 \\
(0.241)\end{array}$ \\
\hline Advanced Degree & $\begin{array}{c}0.319 \\
(0.468)\end{array}$ & $\begin{array}{c}0.352 \\
(0.478)\end{array}$ & $\begin{array}{c}0.353 \\
(0.478)\end{array}$ & $\begin{array}{c}0.379 \\
(0.485)\end{array}$ \\
\hline Teacher Nonwhite & $\begin{array}{c}0.287 \\
(0.454)\end{array}$ & $\begin{array}{l}0.163^{\mathbf{A}} \\
(0.369)\end{array}$ & $\begin{array}{l}0.158^{\mathbf{A}} \\
(0.365)\end{array}$ & $\begin{array}{l}0.185^{A} \\
(0.388)\end{array}$ \\
\hline TPS Students Predominantly White & $\begin{array}{c}0.421 \\
(0.496)\end{array}$ & $\begin{array}{l}0.558^{\mathbf{A}} \\
(0.497)\end{array}$ & $\begin{array}{l}0.572^{\mathbf{A}} \\
(0.495)\end{array}$ & $\begin{array}{c}0.489 \\
(0.500)\end{array}$ \\
\hline Observations & 133 & 74,214 & 68,226 & 26,827 \\
\hline
\end{tabular}

A = significantly different from "mover to charter" category in same time period $(p<0.05)$; $\mathrm{B}=$ significantly different from same sorting category in post-charter-cap-removal time period $(p<0.05)$. Standard errors in parentheses. Sample includes all teachers with value-added scores at urban/suburban TPS from 2007-2015. The "mover to charter" category does not contain every teacher who moves to a charter school since we cannot observe teachers in all charter schools. Some of these teachers will therefore be incorrectly contained in the "leaver" category. 
Table 3: Effects of Charter Growth on TPS Teacher Sorting and Characteristics

\begin{tabular}{|c|c|c|c|c|c|c|c|c|}
\hline & $\begin{array}{c}(1) \\
\text { New Teacher }(\%)\end{array}$ & $\begin{array}{c}(2) \\
\text { New to School }(\%)\end{array}$ & $\begin{array}{c}(3) \\
\text { Turnover }(\%)\end{array}$ & $\begin{array}{c}(4) \\
\text { Teacher V-A }\end{array}$ & $\begin{array}{c}(5) \\
\text { Teacher Exper }\end{array}$ & $\begin{array}{c}(6) \\
\text { Teacher Lat/Prov }\end{array}$ & $\begin{array}{c}(7) \\
\text { Teacher MA }\end{array}$ & $\begin{array}{c}(8) \\
\text { Teacher Nonwhite }\end{array}$ \\
\hline \multicolumn{9}{|c|}{ Extensive Margin: First Charter Entry in 10 Miles } \\
\hline Model 1 (TWFE) & $\begin{array}{c}-2.3823^{* *} \\
(0.942)\end{array}$ & $\begin{array}{c}2.8836^{*} \\
(1.727)\end{array}$ & $\begin{array}{l}1.9920 \\
(2.313)\end{array}$ & $\begin{array}{c}-0.0090 \\
(0.008)\end{array}$ & $\begin{array}{l}0.5204 \\
(0.412)\end{array}$ & $\begin{array}{l}0.4143 \\
(0.894)\end{array}$ & $\begin{array}{l}1.9321 \\
(2.508)\end{array}$ & $\begin{array}{l}1.7802 \\
(1.708)\end{array}$ \\
\hline Model 2 (IV-DiD) & $\begin{array}{r}-3.8443 \\
(3.295)\end{array}$ & $\begin{array}{l}7.7899 \\
(5.113)\end{array}$ & $\begin{array}{l}4.1984 \\
(7.048)\end{array}$ & $\begin{array}{l}0.0053 \\
(0.041)\end{array}$ & $\begin{array}{l}0.3871 \\
(1.742)\end{array}$ & $\begin{array}{l}3.6397 \\
(4.098)\end{array}$ & $\begin{array}{l}3.6424 \\
(8.959)\end{array}$ & $\begin{array}{r}-1.5169 \\
(7.922)\end{array}$ \\
\hline Controls & $\checkmark$ & $\checkmark$ & $\checkmark$ & $\checkmark$ & $\checkmark$ & $\checkmark$ & $\checkmark$ & $\checkmark$ \\
\hline School FE & $\checkmark$ & $\checkmark$ & $\checkmark$ & $\checkmark$ & $\checkmark$ & $\checkmark$ & $\checkmark$ & $\checkmark$ \\
\hline Year FE & $\checkmark$ & $\checkmark$ & $\checkmark$ & $\checkmark$ & $\checkmark$ & $\checkmark$ & $\checkmark$ & $\checkmark$ \\
\hline Observations & 1,797 & 1,797 & 1,737 & 1,961 & 1,960 & 1,961 & 1,956 & 1,960 \\
\hline Model $1 R^{2}$ & 0.203 & 0.251 & 0.339 & 0.276 & 0.223 & 0.267 & 0.206 & 0.280 \\
\hline First Stage $F$ & 36.34 & 36.34 & 40.11 & 40.30 & 40.37 & 40.30 & 39.68 & 40.30 \\
\hline \multicolumn{9}{|c|}{ Intensive Margin: Number of Charters in 10 Miles } \\
\hline Model 1 (TWFE) & $\begin{array}{c}-0.1817^{* *} \\
(0.091)\end{array}$ & $\begin{array}{c}0.3133^{* *} \\
(0.155)\end{array}$ & $\begin{array}{c}-0.3103 \\
(0.259)\end{array}$ & $\begin{array}{l}0.0002 \\
(0.001)\end{array}$ & $\begin{array}{c}0.1239^{* * *} \\
(0.047)\end{array}$ & $\begin{array}{c}-0.0289 \\
(0.136)\end{array}$ & $\begin{array}{c}0.5316^{*} \\
(0.292)\end{array}$ & $\begin{array}{c}0.3596^{*} \\
(0.212)\end{array}$ \\
\hline Model 2 (IV-DiD) & $\begin{array}{c}-1.4806^{* * *} \\
(0.238)\end{array}$ & $\begin{array}{l}0.5889 \\
(0.380)\end{array}$ & $\begin{array}{r}-0.1746 \\
(0.695)\end{array}$ & $\begin{array}{l}0.0017 \\
(0.003)\end{array}$ & $\begin{array}{c}0.3324^{* * *} \\
(0.115)\end{array}$ & $\begin{array}{l}0.0608 \\
(0.375)\end{array}$ & $\begin{array}{c}2.0152^{* * *} \\
(0.600)\end{array}$ & $\begin{array}{c}0.9290^{*} \\
(0.542)\end{array}$ \\
\hline Controls & $\checkmark$ & $\checkmark$ & $\checkmark$ & $\checkmark$ & $\checkmark$ & $\checkmark$ & $\checkmark$ & $\checkmark$ \\
\hline School FE & $\checkmark$ & $\checkmark$ & $\checkmark$ & $\checkmark$ & $\checkmark$ & $\checkmark$ & $\checkmark$ & $\checkmark$ \\
\hline Year FE & $\checkmark$ & $\checkmark$ & $\checkmark$ & $\checkmark$ & $\checkmark$ & $\checkmark$ & $\checkmark$ & $\checkmark$ \\
\hline Observations & 5,606 & 5,606 & 5,322 & 6,010 & 6,001 & 6,010 & 5,998 & 6,009 \\
\hline Model $1 R^{2}$ & 0.225 & 0.192 & 0.224 & 0.250 & 0.223 & 0.301 & 0.215 & 0.235 \\
\hline First Stage $F$ & 505.13 & 505.13 & 522.09 & 867.66 & 856.73 & 867.66 & 856.99 & 865.22 \\
\hline
\end{tabular}

Robust standard errors in parentheses, clustered by school. TWFE = two-way fixed effects models, detrended by pre-treatment school time trends. IV $=$ instrumental variables, with the first stage equations for the extensive and intensive margin presented in Table 3. F-statistics are Kleibergen-Paap rk Wald F statistics. Control variables include county unemployment rate, median income, student enrollment, percent of students by race/ethnicity, and percent of students economically disadvantaged. Estimated coefficients on controls are presented in Table A3. Teacher sorting models are estimated excluding 2007, because they require a lagged count of teachers to calculate each dependent variable.

$* * * \mathrm{p}<0.01, * * \mathrm{p}<0.05, * \mathrm{p}<0.1$ 
Figure 5: Effects of the Proportion of Nearby Charters with Predominantly White Students on TPS Teachers

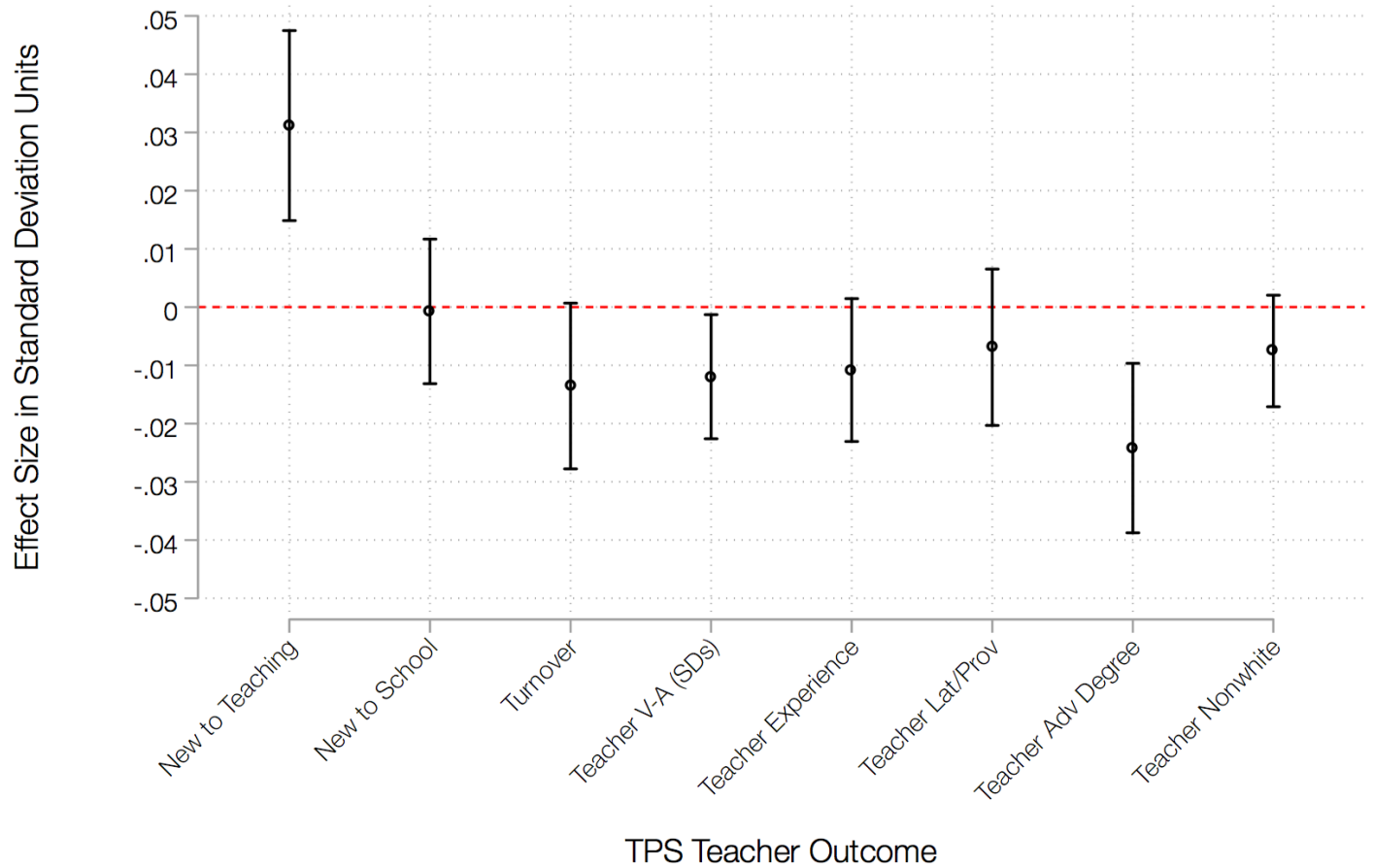

Note. This graph plots a transformation of the estimated coefficient on the measure of the proportion of nearby charters that are predominantly white ( $>80 \%$ of students white). It shows the standard deviation change in each outcome due to changing the nearby charter racial composition from none that are predominantly-white to all that are predominantly-white. The modified Model 2 regression results corresponding to these findings are in Appendix Table A4. 
Figure 6: Effects of the Proportion of Nearby Charters with Predominantly White Students on TPS Teachers, by Racial Composition of TPS

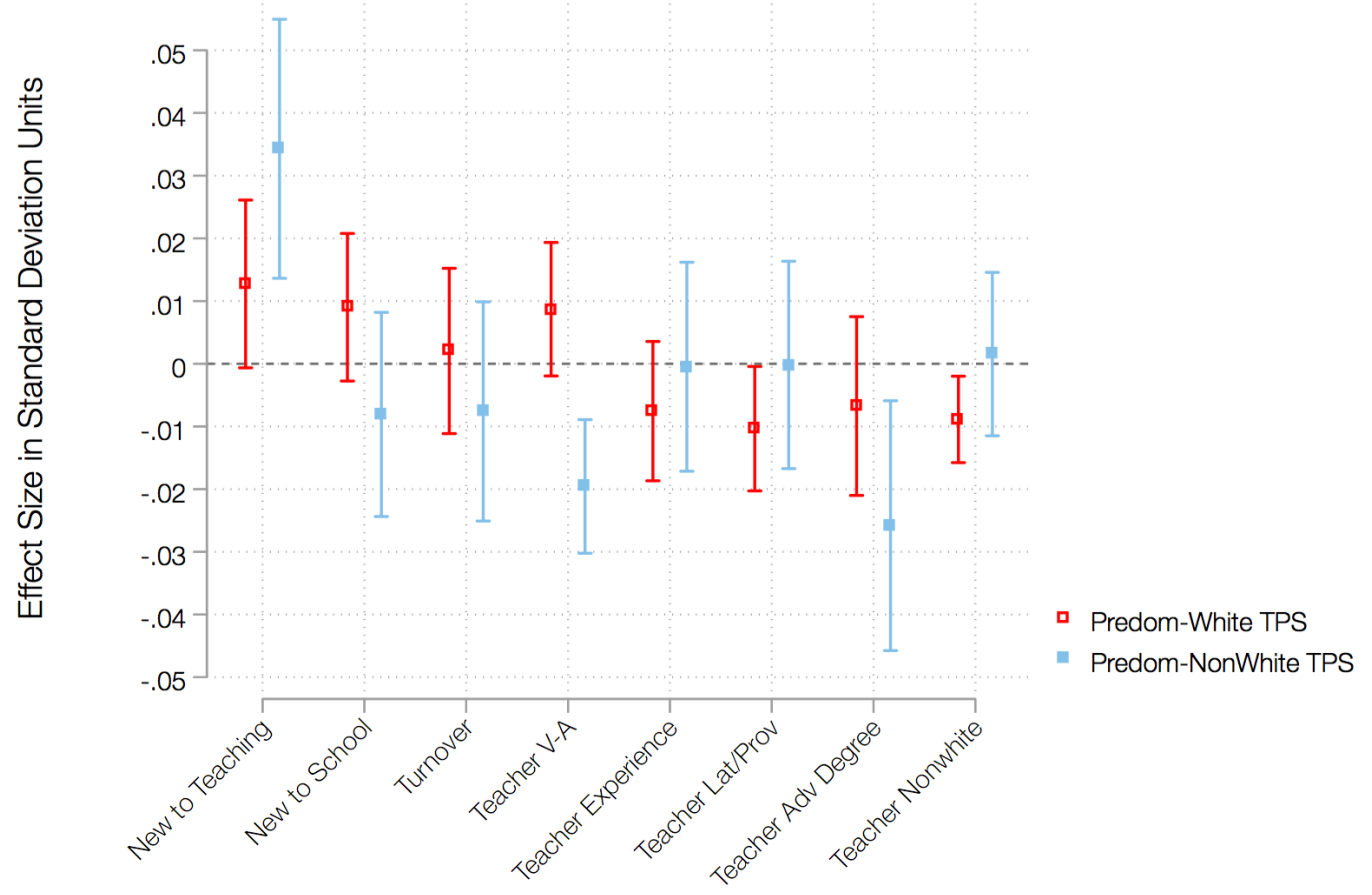

Note. This graph plots a transformation of the estimated coefficient on the measure of the proportion of nearby charters that are predominantly white ( $>80 \%$ of students white). It shows the standard deviation change in each outcome due to changing the nearby charter racial composition from none that are predominantly-white to all that are predominantly-white. It does so separately for different types of TPS by racial composition. Corresponding regression results available upon request. 
Table 4: Effects of Charter Growth on TPS Student Characteristics

\begin{tabular}{|c|c|c|c|c|c|c|}
\hline & $\begin{array}{c}(1) \\
\text { Log Enroll }\end{array}$ & $\begin{array}{c}(2) \\
\text { PTR }\end{array}$ & $\begin{array}{c}(3) \\
\text { White }(\%)\end{array}$ & $\begin{array}{c}(4) \\
\text { Black }(\%)\end{array}$ & $\begin{array}{c}(5) \\
\text { Hispanic }(\%)\end{array}$ & $\begin{array}{c}(6) \\
\operatorname{ED}(\%)\end{array}$ \\
\hline \multicolumn{7}{|c|}{ Extensive Margin: First Charter Entry in 10 Miles } \\
\hline Model 1 (TWFE) & $\begin{array}{l}0.0082 \\
(0.021)\end{array}$ & $\begin{array}{c}-0.0512 \\
(0.187)\end{array}$ & $\begin{array}{l}0.4609 \\
(0.506)\end{array}$ & $\begin{array}{c}-0.6471 \\
(0.536)\end{array}$ & $\begin{array}{l}0.2747 \\
(0.307)\end{array}$ & $\begin{array}{l}0.0649 \\
(0.870)\end{array}$ \\
\hline Model 2 (IV-DiD) & $\begin{array}{l}-0.0961 \\
(0.077)\end{array}$ & $\begin{array}{c}-1.8234^{* *} \\
(0.796)\end{array}$ & $\begin{array}{r}-1.0188 \\
(2.493)\end{array}$ & $\begin{array}{l}-0.8624 \\
(2.498)\end{array}$ & $\begin{array}{l}-0.9188 \\
(1.716)\end{array}$ & $\begin{array}{l}1.9393 \\
(4.281)\end{array}$ \\
\hline Controls & $\checkmark$ & $\checkmark$ & $\checkmark$ & $\checkmark$ & $\checkmark$ & $\checkmark$ \\
\hline School FE & $\checkmark$ & $\checkmark$ & $\checkmark$ & $\checkmark$ & $\checkmark$ & $\checkmark$ \\
\hline Year FE & $\checkmark$ & $\checkmark$ & $\checkmark$ & $\checkmark$ & $\checkmark$ & $\checkmark$ \\
\hline Observations & 1,961 & 1,961 & 1,961 & 1,961 & 1,961 & 1,937 \\
\hline Model $1 R^{2}$ & 0.243 & 0.133 & 0.305 & 0.451 & 0.398 & 0.481 \\
\hline First Stage $F$ & 40.30 & 40.30 & 40.30 & 40.30 & 40.30 & 40.45 \\
\hline \multicolumn{7}{|c|}{ Intensive Margin: Number of Charters in 10 Miles } \\
\hline Model 1 (TWFE) & $\begin{array}{l}0.0024 \\
(0.003)\end{array}$ & $\begin{array}{c}0.0583^{* * *} \\
(0.021)\end{array}$ & $\begin{array}{c}0.1647^{* *} \\
(0.065)\end{array}$ & $\begin{array}{c}-0.1073 \\
(0.083)\end{array}$ & $\begin{array}{r}-0.0010 \\
(0.066)\end{array}$ & $\begin{array}{c}0.3779^{* *} \\
(0.180)\end{array}$ \\
\hline Model 2 (IV-DiD) & $\begin{array}{c}0.0186^{* *} \\
(0.007)\end{array}$ & $\begin{array}{c}0.2929^{* * *} \\
(0.066)\end{array}$ & $\begin{array}{l}0.1697 \\
(0.158)\end{array}$ & $\begin{array}{l}-0.0508 \\
(0.231)\end{array}$ & $\begin{array}{l}-0.2079 \\
(0.206)\end{array}$ & $\begin{array}{l}1.1336 \\
(0.794)\end{array}$ \\
\hline Controls & $\checkmark$ & $\checkmark$ & $\checkmark$ & $\checkmark$ & $\checkmark$ & $\checkmark$ \\
\hline School FE & $\checkmark$ & $\checkmark$ & $\checkmark$ & $\checkmark$ & $\checkmark$ & $\checkmark$ \\
\hline Year FE & $\checkmark$ & $\checkmark$ & $\checkmark$ & $\checkmark$ & $\checkmark$ & $\checkmark$ \\
\hline Observations & 6,005 & 6,010 & 6,010 & 6,010 & 6,010 & 5,827 \\
\hline Model $1 R^{2}$ & 0.277 & 0.291 & 0.234 & 0.974 & 0.283 & 0.149 \\
\hline First Stage $F$ & 874.03 & 867.66 & 867.66 & 867.66 & 867.66 & 739.92 \\
\hline
\end{tabular}

Robust standard errors in parentheses, clustered by school. PTR = pupil-teacher ratio. TWFE = two-way fixed effects models, detrended by pre-treatment school time trends. IV = instrumental variables, with the first stage equations for the extensive and intensive margin presented in Table 3. F-statistics are KleibergenPaap rk Wald F statistics. Control variables include county unemployment rate, median income, student enrollment, percent of students by race/ethnicity, and percent of students economically disadvantaged. $* * * \mathrm{p}<0.01,{ }^{* *} \mathrm{p}<0.05,{ }^{*} \mathrm{p}<0.1$ 


\section{Appendix}

Figure A1: Number of Charter Schools by Economic Disadvantage 2006-2016

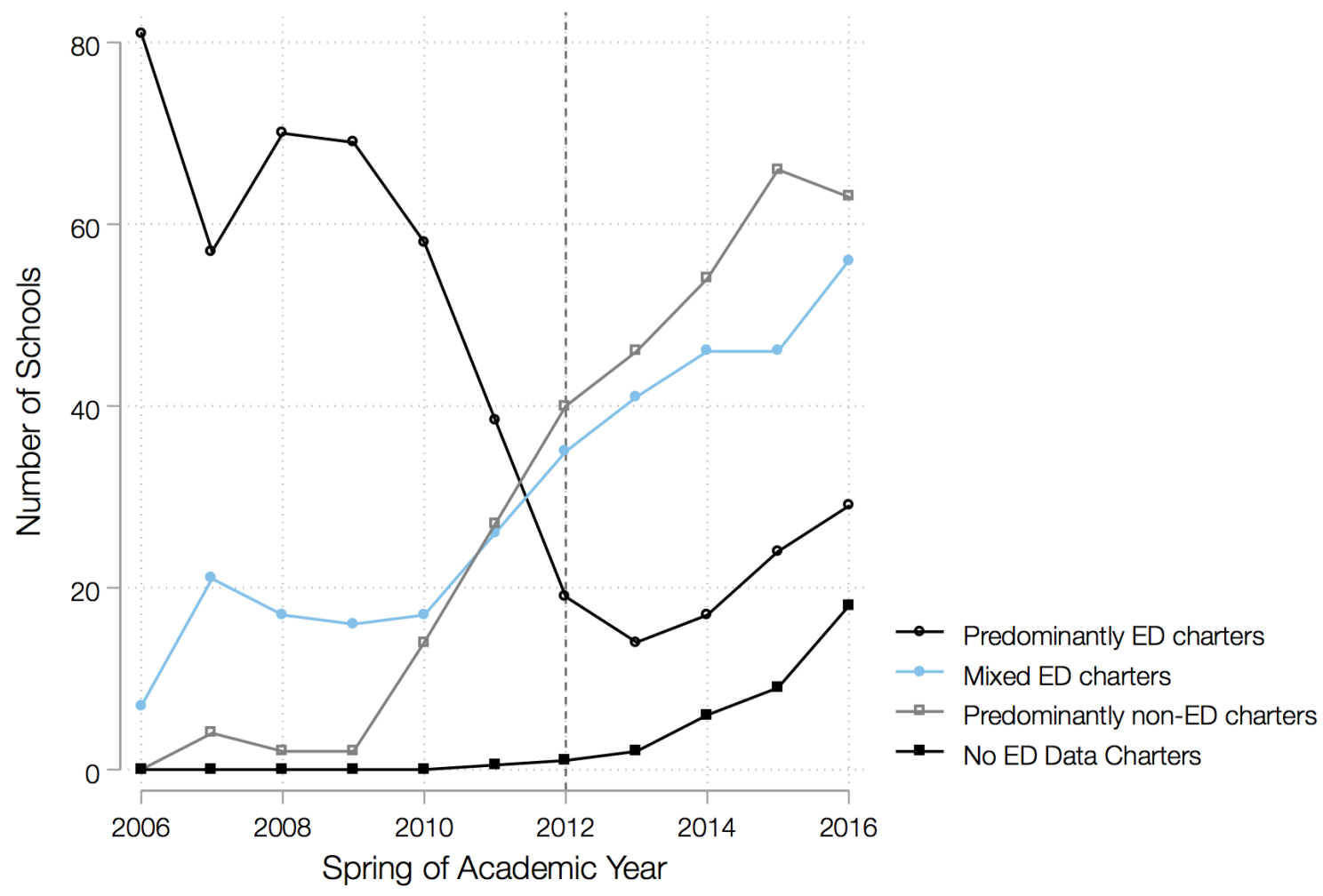

Note. ED = economically-disadvantaged students. The removal of the charter cap in 2012 is signified by a vertical dashed line. Because of irregularities in reporting of free lunch eligibility in 2011, values for that school year are imputed as the average of 2010 and 2012 values. Predominantly-ED charters have greater than $80 \%$ ED students, predominantly non-ED charters have less than $20 \%$ ED students, and mixed-ED charters have somewhere in the middle. Because charter schools are not forced to participate in the National School Lunch program, there are also some charter schools with no ED data available. 
Table A1: First Stage Results

\begin{tabular}{|c|c|c|c|c|}
\hline \multicolumn{2}{|l|}{$\begin{array}{l}\text { Distance } \\
\text { (Radius) }\end{array}$} & $\begin{array}{c}(1) \\
\text { First Charter Entry }\end{array}$ & $\begin{array}{c}(2) \\
\text { Count of Charters }\end{array}$ & $\begin{array}{c}(3) \\
\text { Charter Share Enrolled }\end{array}$ \\
\hline$\underline{2 \text { Miles }}$ & $\begin{array}{l}\beta \\
\text { SE } \\
\text { F-stat } \\
R^{2} \\
\mathrm{~N}\end{array}$ & $\begin{array}{c}0.0768^{* * *} \\
(0.016) \\
22.52 \\
0.392 \\
6,045\end{array}$ & $\begin{array}{c}0.0246 \\
(0.031) \\
0.64 \\
0.752 \\
1,926\end{array}$ & $\begin{array}{c}-0.1007 \\
(0.318) \\
0.10 \\
0.720 \\
1,926\end{array}$ \\
\hline$\underline{10 \text { Miles }}$ & $\begin{array}{l}\beta \\
\text { SE } \\
\text { F-stat } \\
R^{2} \\
\mathrm{~N}\end{array}$ & $\begin{array}{c}0.1286^{* * *} \\
(0.020) \\
40.30 \\
0.413 \\
1,961\end{array}$ & $\begin{array}{c}0.2749 * * * \\
(0.009) \\
867.66 \\
0.934 \\
6,010\end{array}$ & $\begin{array}{c}0.1653^{* * *} \\
(0.017) \\
92.81 \\
0.833 \\
6,010\end{array}$ \\
\hline$\underline{20 \text { Miles }}$ & $\begin{array}{l}\beta \\
\text { SE } \\
\text { F-stat } \\
R^{2} \\
\mathrm{~N}\end{array}$ & $\begin{array}{c}0.1016^{* * *} \\
(0.035) \\
8.38 \\
0.564 \\
536\end{array}$ & $\begin{array}{c}0.2605^{* * *} \\
(0.009) \\
848.91 \\
0.964 \\
7,450\end{array}$ & $\begin{array}{c}0.1295^{* * *} \\
(0.006) \\
484.88 \\
0.891 \\
7,450\end{array}$ \\
\hline $\begin{array}{l}\text { Control } \\
\text { School F } \\
\text { Year Fix }\end{array}$ & $\begin{array}{l}\text { ariables } \\
\text { zed Effects } \\
\text { d Effects }\end{array}$ & $\begin{array}{l}\checkmark \\
\checkmark \\
\checkmark\end{array}$ & $\begin{array}{l}\checkmark \\
\checkmark \\
\checkmark\end{array}$ & $\begin{array}{l}\checkmark \\
\checkmark \\
\checkmark\end{array}$ \\
\hline
\end{tabular}

Each $\beta$ coefficient is the estimated coefficient on the instrumental variable (number of pre-cap-removal charter applications in 10 miles multiplied by a "Post" indicator). Column 1 models are estimated using an extensive margin sample, which includes all TPS without any charters in $x$ miles by 2012 . Columns 2 and 3 models are estimated using an intensive margin sample which includes all TPS with at least one charter in $x$ miles by 2012. Robust standard errors are in parentheses, clustered by school. F-statistics are Kleibergen-Paap rk Wald F statistics. Control variables include county unemployment rate, median income, student enrollment, percent of students by race/ethnicity, and percent of students economically disadvantaged.

$* * * \mathrm{p}<0.01,{ }^{*} * \mathrm{p}<0.05,{ }^{*} \mathrm{p}<0.1$ 
Table A2: Descriptive Statistics of TPS by Number of Charters Within 10 Miles

\begin{tabular}{|c|c|c|c|c|c|}
\hline & (1) & $(2)$ & $(3)$ & (4) & $(5)$ \\
\hline & 0 & 1 & $2-3$ & $4-6$ & $7+$ \\
\hline \multirow[t]{2}{*}{ Elementary school } & 0.624 & 0.642 & 0.656 & 0.700 & 0.681 \\
\hline & $(0.485)$ & $(0.479)$ & $(0.475)$ & $(0.458)$ & $(0.466)$ \\
\hline \multirow[t]{2}{*}{ Middle school } & 0.270 & 0.269 & 0.255 & 0.231 & 0.227 \\
\hline & $(0.444)$ & $(0.443)$ & $(0.436)$ & $(0.421)$ & $(0.419)$ \\
\hline \multirow[t]{2}{*}{ Other grade range } & 0.106 & 0.089 & 0.090 & 0.070 & 0.091 \\
\hline & $(0.308)$ & $(0.284)$ & $(0.286)$ & $(0.254)$ & $(0.288)$ \\
\hline \multirow[t]{2}{*}{ Located in city } & 0.146 & 0.333 & 0.386 & 0.735 & 0.866 \\
\hline & $(0.353)$ & $(0.471)$ & $(0.487)$ & $(0.441)$ & $(0.341)$ \\
\hline \multirow{2}{*}{ Located in suburb/town } & 0.307 & 0.305 & 0.448 & 0.265 & 0.134 \\
\hline & $(0.461)$ & $(0.460)$ & $(0.497)$ & $(0.441)$ & $(0.341)$ \\
\hline \multirow[t]{2}{*}{ Teachers new to teaching (\%) } & 4.870 & 4.654 & 3.374 & 4.301 & 4.673 \\
\hline & $(7.704)$ & $(8.385)$ & $(6.431)$ & $(7.315)$ & $(7.616)$ \\
\hline \multirow[t]{2}{*}{ Teachers new to school (\%) } & 7.005 & 7.042 & 6.953 & 8.049 & 8.692 \\
\hline & $(11.584)$ & $(11.255)$ & $(10.753)$ & $(10.610)$ & $(11.090)$ \\
\hline \multirow[t]{2}{*}{ Teacher turnover (\%) } & 27.888 & 29.612 & 28.786 & 30.721 & 33.697 \\
\hline & $(20.009)$ & $(20.692)$ & $(20.781)$ & $(19.846)$ & $(20.760)$ \\
\hline \multirow[t]{2}{*}{ Teacher value-added } & -0.004 & 0.001 & 0.017 & 0.024 & 0.028 \\
\hline & $(0.091)$ & $(0.095)$ & $(0.094)$ & $(0.086)$ & $(0.087)$ \\
\hline \multirow[t]{2}{*}{ Teacher experience } & 12.128 & 11.992 & 12.245 & 11.880 & 10.929 \\
\hline & $(4.124)$ & $(4.450)$ & $(4.010)$ & $(4.161)$ & $(4.200)$ \\
\hline \multirow[t]{2}{*}{ Teacher lateral/provisional } & 5.791 & 6.236 & 5.776 & 5.607 & 6.337 \\
\hline & $(9.830)$ & $(10.390)$ & $(10.703)$ & $(8.797)$ & $(10.012)$ \\
\hline \multirow[t]{2}{*}{ Teacher advanced degree } & 30.937 & 31.180 & 35.919 & 38.628 & 41.725 \\
\hline & $(19.917)$ & $(19.254)$ & $(21.088)$ & $(18.304)$ & $(19.891)$ \\
\hline \multirow[t]{2}{*}{ Teacher non-white } & 15.040 & 23.308 & 15.990 & 25.767 & 28.735 \\
\hline & $(20.058)$ & $(26.402)$ & $(22.339)$ & $(23.334)$ & $(22.904)$ \\
\hline \multirow[t]{2}{*}{ Total student enrollment } & 504.639 & 522.332 & 590.020 & 651.264 & 686.488 \\
\hline & $(214.285)$ & $(234.954)$ & $(285.637)$ & $(279.217)$ & $(294.369)$ \\
\hline \multirow[t]{2}{*}{ Percent of students white } & 51.194 & 43.524 & 52.354 & 34.998 & 29.841 \\
\hline & $(23.470)$ & $(26.659)$ & $(25.835)$ & $(26.709)$ & $(23.029)$ \\
\hline \multirow[t]{2}{*}{ Percent of students black } & 28.710 & 35.857 & 28.440 & 37.709 & 41.645 \\
\hline & $(22.024)$ & $(26.448)$ & $(23.932)$ & $(24.438)$ & $(20.460)$ \\
\hline \multirow[t]{2}{*}{ Percent students Hispanic } & 13.145 & 13.277 & 12.432 & 18.796 & 21.073 \\
\hline & $(10.558)$ & $(11.643)$ & $(10.225)$ & $(15.032)$ & $(14.532)$ \\
\hline \multirow[t]{2}{*}{ Percent students ED } & 0.648 & 0.641 & 0.535 & 0.588 & 0.558 \\
\hline & $(0.193)$ & $(0.222)$ & $(0.280)$ & $(0.305)$ & $(0.884)$ \\
\hline \multirow[t]{2}{*}{ County unemployment rate } & 8.665 & 8.018 & 7.710 & 7.174 & 6.644 \\
\hline & $(2.820)$ & $(2.656)$ & $(2.457)$ & $(2.132)$ & $(2.189)$ \\
\hline \multirow[t]{2}{*}{ County median income } & 51994.562 & 54851.895 & 59533.122 & 62767.034 & 70008.778 \\
\hline & $(7364.825)$ & $(9164.808)$ & $(7595.077)$ & $(6928.866)$ & $(5623.066)$ \\
\hline Observations & 2262 & 2243 & 1736 & 1453 & 1686 \\
\hline
\end{tabular}

Means, with standard errors in parentheses; sample includes all urban/suburban TPS. 
Table A3: Coefficients on Control Variables from Intensive Margin TWFE Model

\begin{tabular}{|c|c|c|c|c|c|c|c|c|}
\hline & $\begin{array}{c}(1) \\
\text { New Teacher }(\%)\end{array}$ & $\begin{array}{c}(2) \\
\text { New to School }(\%)\end{array}$ & $\begin{array}{c}(3) \\
\text { Turnover (\%) }\end{array}$ & $\begin{array}{c}(4) \\
\text { Teacher V-A }\end{array}$ & $\begin{array}{c}(5) \\
\text { Teacher Exper }\end{array}$ & $\begin{array}{c}(6) \\
\text { Teacher Lat/Prov }\end{array}$ & $\begin{array}{c}(7) \\
\text { Teacher MA }\end{array}$ & $\begin{array}{c}(8) \\
\text { Teacher Nonwhite }\end{array}$ \\
\hline County unemployment rate & $\begin{array}{c}-0.9100^{* * *} \\
(0.182)\end{array}$ & $\begin{array}{c}0.5824^{*} \\
(0.300)\end{array}$ & $\begin{array}{c}-0.8992^{*} \\
(0.538)\end{array}$ & $\begin{array}{l}0.0024 \\
(0.002)\end{array}$ & $\begin{array}{l}0.0549 \\
(0.101)\end{array}$ & $\begin{array}{l}0.1899 \\
(0.249)\end{array}$ & $\begin{array}{l}0.7666 \\
(0.532)\end{array}$ & $\begin{array}{l}0.4395 \\
(0.364)\end{array}$ \\
\hline County median income & $\begin{array}{r}-0.0001 \\
(0.000)\end{array}$ & $\begin{array}{l}-0.0001 \\
(0.000)\end{array}$ & $\begin{array}{l}-0.0002 \\
(0.000)\end{array}$ & $\begin{array}{l}0.0000 \\
(0.000)\end{array}$ & $\begin{array}{c}0.0001^{*} \\
(0.000)\end{array}$ & $\begin{array}{r}-0.0000 \\
(0.000)\end{array}$ & $\begin{array}{r}-0.0001 \\
(0.000)\end{array}$ & $\begin{array}{r}-0.0000 \\
(0.000)\end{array}$ \\
\hline County student enrollment & $\begin{array}{l}0.0000 \\
(0.000)\end{array}$ & $\begin{array}{l}0.0001 \\
(0.000)\end{array}$ & $\begin{array}{l}0.0002 \\
(0.000)\end{array}$ & $\begin{array}{c}0.0000^{* *} \\
(0.000)\end{array}$ & $\begin{array}{r}-0.0000 \\
(0.000)\end{array}$ & $\begin{array}{l}0.0000 \\
(0.000)\end{array}$ & $\begin{array}{c}-0.0002^{* *} \\
(0.000)\end{array}$ & $\begin{array}{c}-0.0002^{* *} \\
(0.000)\end{array}$ \\
\hline County percent students black & $\begin{array}{c}-0.1694^{*} \\
(0.090)\end{array}$ & $\begin{array}{l}0.0962 \\
(0.230)\end{array}$ & $\begin{array}{l}0.3486 \\
(0.632)\end{array}$ & $\begin{array}{l}0.0002 \\
(0.001)\end{array}$ & $\begin{array}{c}0.1692^{* * *} \\
(0.059)\end{array}$ & $\begin{array}{l}0.1598 \\
(0.263)\end{array}$ & $\begin{array}{l}0.1795 \\
(0.274)\end{array}$ & $\begin{array}{c}0.6951^{* * *} \\
(0.266)\end{array}$ \\
\hline County students Hispanic & $\begin{array}{l}0.0496 \\
(0.155)\end{array}$ & $\begin{array}{r}-0.1933 \\
(0.250)\end{array}$ & $\begin{array}{l}0.4650 \\
(0.668)\end{array}$ & $\begin{array}{c}-0.0047^{* * *} \\
(0.002)\end{array}$ & $\begin{array}{r}-0.0801 \\
(0.089)\end{array}$ & $\begin{array}{l}0.2285 \\
(0.246)\end{array}$ & $\begin{array}{c}-0.8412^{* *} \\
(0.406)\end{array}$ & $\begin{array}{l}0.4840 \\
(0.339)\end{array}$ \\
\hline County students other race & $\begin{array}{c}-0.0536 \\
(0.150)\end{array}$ & $\begin{array}{c}-0.4301^{*} \\
(0.241)\end{array}$ & $\begin{array}{l}0.2020 \\
(0.462)\end{array}$ & $\begin{array}{l}0.0006 \\
(0.001)\end{array}$ & $\begin{array}{l}0.1019 \\
(0.089)\end{array}$ & $\begin{array}{l}-0.3333 \\
(0.228)\end{array}$ & $\begin{array}{r}-0.5180 \\
(0.440)\end{array}$ & $\begin{array}{l}0.1783 \\
(0.342)\end{array}$ \\
\hline County percent students ED & $\begin{array}{l}-0.0007 \\
(0.019)\end{array}$ & $\begin{array}{l}-0.0051 \\
(0.031)\end{array}$ & $\begin{array}{l}0.0449 \\
(0.058)\end{array}$ & $\begin{array}{c}0.0003^{*} \\
(0.000)\end{array}$ & $\begin{array}{l}-0.0012 \\
(0.009)\end{array}$ & $\begin{array}{l}0.0203 \\
(0.022)\end{array}$ & $\begin{array}{r}-0.0067 \\
(0.051)\end{array}$ & $\begin{array}{r}-0.0510 \\
(0.038)\end{array}$ \\
\hline Observations & 5,606 & 5,606 & 5,322 & 6,010 & 6,001 & 6,010 & 5,998 & 6,009 \\
\hline$R^{2}$ & 0.225 & 0.192 & 0.224 & 0.250 & 0.223 & 0.301 & 0.215 & 0.235 \\
\hline
\end{tabular}

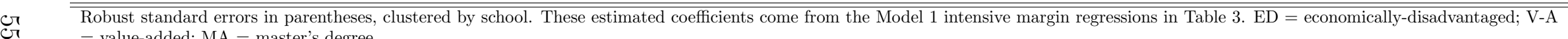
ter's degree.

$* * * \mathrm{p}<0.01,{ }^{* *} \mathrm{p}<0.05,{ }^{*} \mathrm{p}<0.1$ 
Table A4: Effects of Nearby Charter Racial Composition on TPS Teachers

\begin{tabular}{|c|c|c|c|c|c|c|c|c|}
\hline & $\begin{array}{c}(1) \\
\text { New Teacher }(\%)\end{array}$ & $\begin{array}{c}(2) \\
\text { New to School }(\%) \\
\end{array}$ & $\begin{array}{c}(3) \\
\text { Turnover }(\%)\end{array}$ & $\begin{array}{c}(4) \\
\text { Teacher V-A }\end{array}$ & $\begin{array}{c}(5) \\
\text { Teacher Exper }\end{array}$ & $\begin{array}{c}(6) \\
\text { Teacher Lat/Prov }\end{array}$ & $\begin{array}{c}(7) \\
\text { Teacher MA }\end{array}$ & $\begin{array}{c}(8) \\
\text { Teacher Nonwhite }\end{array}$ \\
\hline \multicolumn{9}{|l|}{$\underline{\text { All TPS }}$} \\
\hline Share of charters predominantly-White & $\begin{array}{c}0.2396 * * * \\
(0.064)\end{array}$ & $\begin{array}{r}-0.0090 \\
(0.077)\end{array}$ & $\begin{array}{c}-0.2781^{*} \\
(0.149)\end{array}$ & $\begin{array}{c}-0.0011^{* *} \\
(0.001)\end{array}$ & $\begin{array}{c}-0.0458^{*} \\
(0.027)\end{array}$ & $\begin{array}{l}-0.0695 \\
(0.069)\end{array}$ & $\begin{array}{c}-0.4893^{* * *} \\
(0.150)\end{array}$ & $\begin{array}{l}-0.1791 \\
(0.116)\end{array}$ \\
\hline Number of charters in 10 mile radius & $\begin{array}{c}-0.1134 \\
(0.161)\end{array}$ & $\begin{array}{l}0.3886^{*} \\
(0.229)\end{array}$ & $\begin{array}{l}0.0889 \\
(0.418)\end{array}$ & $\begin{array}{r}-0.0006 \\
(0.001)\end{array}$ & $\begin{array}{l}-0.0099 \\
(0.069)\end{array}$ & $\begin{array}{r}-0.0680 \\
(0.204)\end{array}$ & $\begin{array}{c}-0.9646^{* *} \\
(0.477)\end{array}$ & $\begin{array}{l}0.3050 \\
(0.302)\end{array}$ \\
\hline Observations & 5,275 & 5,275 & 5,275 & 5,424 & 5,418 & 5,424 & 5,416 & 5,424 \\
\hline First Stage $F$ & 19.41 & 19.41 & 19.41 & 19.91 & 19.70 & 19.91 & 19.69 & 19.91 \\
\hline \multicolumn{9}{|l|}{ Predominantly-White TPS } \\
\hline Share of charters predominantly-White & $\begin{array}{c}0.0979^{*} \\
(0.053)\end{array}$ & $\begin{array}{l}0.1095 \\
(0.073)\end{array}$ & $\begin{array}{l}0.0419 \\
(0.138)\end{array}$ & $\begin{array}{l}0.0008 \\
(0.001)\end{array}$ & $\begin{array}{r}-0.0320 \\
(0.024)\end{array}$ & $\begin{array}{c}-0.1044^{* *} \\
(0.051)\end{array}$ & $\begin{array}{r}-0.1363 \\
(0.147)\end{array}$ & $\begin{array}{c}-0.2110^{* *} \\
(0.084)\end{array}$ \\
\hline Number of charters in 10 mile radius & $\begin{array}{l}-0.1941 \\
(0.377)\end{array}$ & $\begin{array}{l}0.7662 \\
(0.592)\end{array}$ & $\begin{array}{l}-0.7382 \\
(1.129)\end{array}$ & $\begin{array}{c}0.000 \\
(0.004)\end{array}$ & $\begin{array}{r}-0.0306 \\
(0.191)\end{array}$ & $\begin{array}{l}0.2579 \\
(0.308)\end{array}$ & $\begin{array}{l}-0.3103 \\
(1.208)\end{array}$ & $\begin{array}{l}-0.5643 \\
(0.603)\end{array}$ \\
\hline Observations & 2,001 & 2,001 & 2,001 & 2,062 & 2,059 & 2,062 & 2,058 & 2,062 \\
\hline First Stage $F$ & 5.90 & 5.90 & 5.90 & 6.79 & 6.76 & 6.79 & 6.77 & 6.79 \\
\hline \multicolumn{9}{|l|}{ Predominantly-Nonwhite TPS } \\
\hline Share of charters predominantly-White & $\begin{array}{c}0.2636^{* * *} \\
(0.081)\end{array}$ & $\begin{array}{r}-0.0983 \\
(0.101)\end{array}$ & $\begin{array}{r}-.01561 \\
(0.183)\end{array}$ & $\begin{array}{c}-0.0018^{* * *} \\
(0.001)\end{array}$ & $\begin{array}{r}-0.0020 \\
(0.036)\end{array}$ & $\begin{array}{r}-0.0019 \\
(0.085)\end{array}$ & $\begin{array}{c}-0.5220^{* *} \\
(0.206)\end{array}$ & $\begin{array}{l}0.0366 \\
(0.158)\end{array}$ \\
\hline Number of charters in 10 mile radius & $\begin{array}{r}-0.2348 \\
(0.189)\end{array}$ & $\begin{array}{l}0.3109 \\
(0.297)\end{array}$ & $\begin{array}{l}0.0878 \\
(0.498)\end{array}$ & $\begin{array}{l}-0.0024 \\
(0.002)\end{array}$ & $\begin{array}{l}0.0673 \\
(0.075)\end{array}$ & $\begin{array}{l}-01071 \\
(0.232)\end{array}$ & $\begin{array}{l}-0.8106 \\
(0.570)\end{array}$ & $\begin{array}{l}0.3831 \\
(0.379)\end{array}$ \\
\hline Observations & 3,242 & 3,242 & 3,242 & 3,329 & 3,326 & 3,329 & 3,325 & 3,329 \\
\hline First Stage $F$ & 16.20 & 16.20 & 16.20 & 16.20 & 16.10 & 16.20 & 16.11 & 16.20 \\
\hline
\end{tabular}
students White (scaled from 0 to 1). F-statistics are Kleibergen-Paap rk Wald F statistics. Control variables include county unemployment rate, median income, student enrollment, percent of students by race/ethnicity, and percent of students economically disadvantaged.

$* * * \mathrm{p}<0.01, * * \mathrm{p}<0.05, * \mathrm{p}<0.1$ 
Table A5: Effects of Intensive Charter Growth on TPS Student Sorting

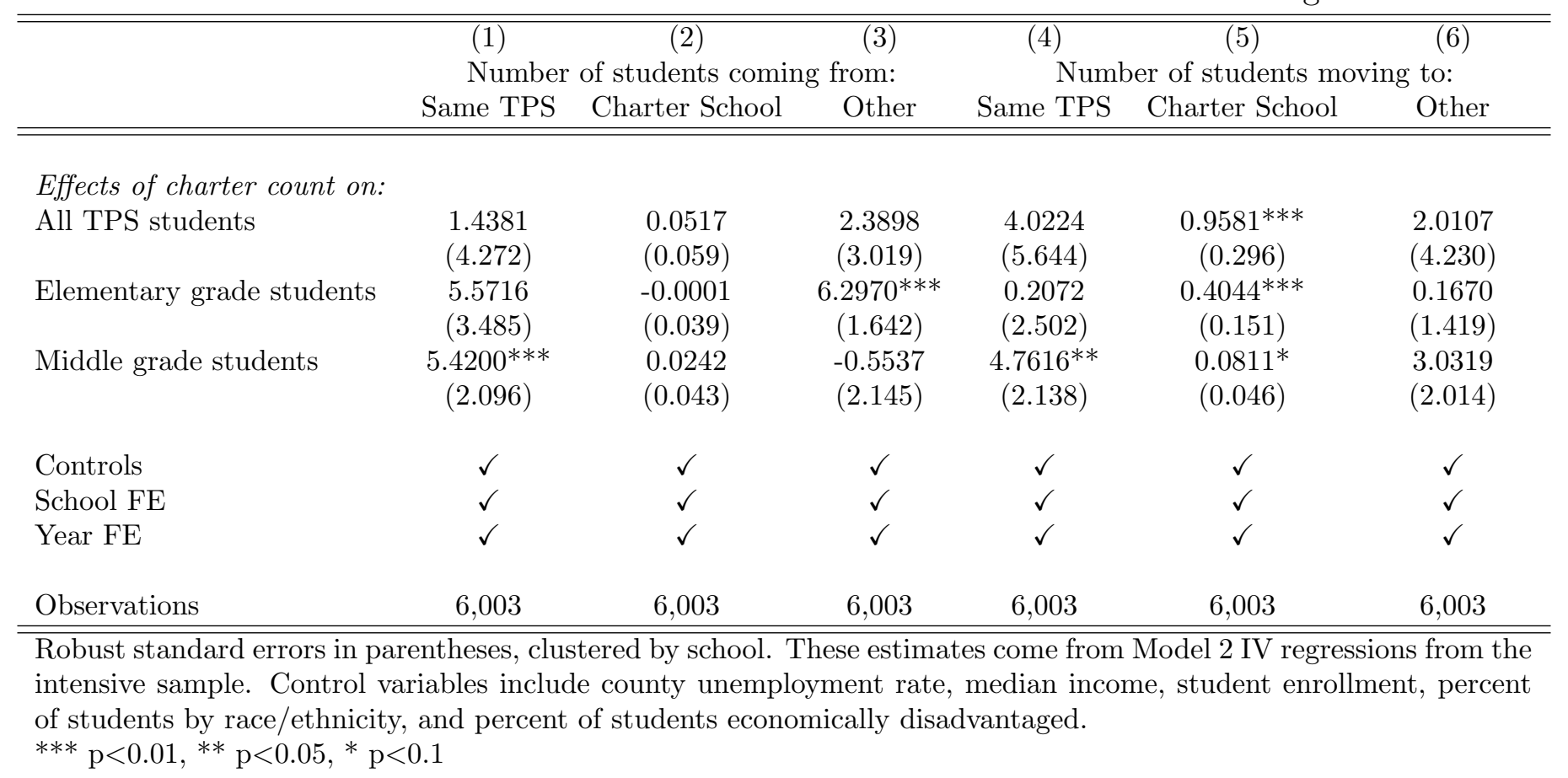


Table A6: Effect of Charter Growth on TPS Teachers, Alternative Enrollment Share Measure

\begin{tabular}{|c|c|c|c|c|c|c|c|c|}
\hline & $\begin{array}{c}(1) \\
\text { New Teacher (\%) }\end{array}$ & $\begin{array}{c}(2) \\
\text { New to School }(\%) \\
\end{array}$ & $\begin{array}{c}(3) \\
\text { Turnover }(\%) \\
\end{array}$ & $\begin{array}{c}(4) \\
\text { Teacher V-A }\end{array}$ & $\begin{array}{c}(5) \\
\text { Teacher Exper }\end{array}$ & $\begin{array}{c}(6) \\
\text { Teacher Lat/Prov }\end{array}$ & $\begin{array}{c}(7) \\
\text { Teacher MA }\end{array}$ & $\begin{array}{c}(8) \\
\text { Teacher Nonwhite }\end{array}$ \\
\hline \multicolumn{9}{|c|}{ Intensive Margin: Charter Share of Total Enrollment in 10 Miles } \\
\hline Model 1 (TWFE) & $\begin{array}{c}-0.1278^{* *} \\
(0.051)\end{array}$ & $\begin{array}{l}-0.0355 \\
(0.093)\end{array}$ & $\begin{array}{c}-0.1369 \\
(0.196)\end{array}$ & $\begin{array}{l}-0.0006 \\
(0.001)\end{array}$ & $\begin{array}{c}0.1528^{* * *} \\
(0.032)\end{array}$ & $\begin{array}{c}-0.1642^{* *} \\
(0.074)\end{array}$ & $\begin{array}{c}0.6429^{* * *} \\
(0.168)\end{array}$ & $\begin{array}{l}0.1042 \\
(0.123)\end{array}$ \\
\hline Model 2 (IV-DiD) & $\begin{array}{c}-2.0891^{* * * *} \\
(0.388)\end{array}$ & $\begin{array}{l}1.0564^{*} \\
(0.539)\end{array}$ & $\begin{array}{l}0.5463 \\
(0.951)\end{array}$ & $\begin{array}{l}0.0040 \\
(0.004)\end{array}$ & $\begin{array}{c}0.5924^{* * *} \\
(0.184)\end{array}$ & $\begin{array}{l}0.0181 \\
(0.653)\end{array}$ & $\begin{array}{c}3.0842^{* * *} \\
(1.007)\end{array}$ & $\begin{array}{l}1.1782 \\
(0.854)\end{array}$ \\
\hline Controls & $\checkmark$ & $\checkmark$ & $\checkmark$ & $\checkmark$ & $\checkmark$ & $\checkmark$ & $\checkmark$ & $\checkmark$ \\
\hline School FE & $\checkmark$ & $\checkmark$ & $\checkmark$ & $\checkmark$ & $\checkmark$ & $\checkmark$ & $\checkmark$ & $\checkmark$ \\
\hline Year FE & $\checkmark$ & $\checkmark$ & $\checkmark$ & $\checkmark$ & $\checkmark$ & $\checkmark$ & $\checkmark$ & $\checkmark$ \\
\hline Observations & 5,606 & 5,606 & 5,322 & 6,010 & 6,001 & 6,010 & 5,998 & 6,009 \\
\hline Model $1 R^{2}$ & 0.225 & 0.191 & 0.224 & 0.250 & 0.228 & 0.302 & 0.217 & 0.233 \\
\hline First Stage $F$ & 100.47 & 100.47 & 105.83 & 92.82 & 92.11 & 92.82 & 91.92 & 92.75 \\
\hline
\end{tabular}

Robust standard errors in parentheses, clustered by school. TWFE = two-way fixed effects models, detrended by pre-treatment school time trends. IV $=$ instrumental variables, with the first stage equations for the extensive and intensive margin presented in Table 3. F-statistics are Kleibergen-Paap rk Wald F statistics. Control variables include county unemployment rate, median income, student enrollment, percent of students by race/ethnicity, and percent of students economically disadvantaged. Teacher sorting models are estimated excluding 2007 , because they require a lagged count of teachers to calculate each dependent variable. 
Table A7: Effect of Charter Growth on TPS Teachers, Alternative Radii

\begin{tabular}{|c|c|c|c|c|c|c|c|c|}
\hline & $\begin{array}{c}(1) \\
\text { New Teacher }(\%)\end{array}$ & $\begin{array}{c}(2) \\
\text { New to School }(\%)\end{array}$ & $\begin{array}{c}(3) \\
\text { Turnover (\%) }\end{array}$ & $\begin{array}{c}(4) \\
\text { Teacher V-A }\end{array}$ & $\begin{array}{c}(5) \\
\text { Teacher Exper }\end{array}$ & $\begin{array}{c}(6) \\
\text { Teacher Lat/Prov }\end{array}$ & $\begin{array}{c}(7) \\
\text { Teacher MA }\end{array}$ & $\begin{array}{c}\text { (8) } \\
\text { Teacher Nonwhite }\end{array}$ \\
\hline \multicolumn{9}{|c|}{ Extensive Margin: First Charter Entry in 2 Miles } \\
\hline Model 1 (TWFE) & $\begin{array}{r}-0.2810 \\
(0.583)\end{array}$ & $\begin{array}{l}-0.2317 \\
(1.111)\end{array}$ & $\begin{array}{c}-2.7604^{*} \\
(1.635)\end{array}$ & $\begin{array}{c}-0.0093^{*} \\
(0.005)\end{array}$ & $\begin{array}{l}0.2050 \\
(0.318)\end{array}$ & $\begin{array}{c}1.3480^{* *} \\
(0.645)\end{array}$ & $\begin{array}{l}2.6833 \\
(1.784)\end{array}$ & $\begin{array}{l}-0.9847 \\
(1.346)\end{array}$ \\
\hline Model 2 (IV-DiD) & $\begin{array}{l}-3.3426 \\
(4.354)\end{array}$ & $\begin{array}{l}6.2955 \\
(5.899)\end{array}$ & $\begin{array}{c}4.2816 \\
(11.565)\end{array}$ & $\begin{array}{r}-0.0255 \\
(0.039)\end{array}$ & $\begin{array}{l}2.2535 \\
(1.723)\end{array}$ & $\begin{array}{c}13.1776^{*} \\
(7.773)\end{array}$ & $\begin{array}{l}12.9094 \\
(9.669)\end{array}$ & $\begin{array}{l}-8.1560 \\
(8.538)\end{array}$ \\
\hline Controls & $\checkmark$ & $\checkmark$ & $\checkmark$ & $\checkmark$ & $\checkmark$ & $\checkmark$ & $\checkmark$ & $\checkmark$ \\
\hline School FE & $\checkmark$ & $\checkmark$ & $\checkmark$ & $\checkmark$ & $\checkmark$ & $\checkmark$ & $\checkmark$ & $\checkmark$ \\
\hline Year FE & $\checkmark$ & $\checkmark$ & $\checkmark$ & $\checkmark$ & $\checkmark$ & $\checkmark$ & $\checkmark$ & $\checkmark$ \\
\hline Observations & 5,608 & 5,608 & 5,342 & 6,045 & 6,037 & 6,045 & 6,031 & 6,043 \\
\hline Model $1 R^{2}$ & 0.195 & 0.208 & 0.253 & 0.258 & 0.215 & 0.293 & 0.218 & 0.250 \\
\hline First Stage $F$ & 22.63 & 22.63 & 22.33 & 22.52 & 22.78 & 22.52 & 22.76 & 22.52 \\
\hline \multicolumn{9}{|c|}{ Intensive Margin: Number of Charters in 20 Miles } \\
\hline Model 1 (TWFE) & $\begin{array}{r}-0.0826 \\
(0.055)\end{array}$ & $\begin{array}{c}0.2205^{* *} \\
(0.098)\end{array}$ & $\begin{array}{l}-0.2492 \\
(0.166)\end{array}$ & $\begin{array}{c}-0.0006 \\
(0.001)\end{array}$ & $\begin{array}{c}0.0938^{* * *} \\
(0.026)\end{array}$ & $\begin{array}{c}-0.1120 \\
(0.087)\end{array}$ & $\begin{array}{c}0.2819^{*} \\
(0.153)\end{array}$ & $\begin{array}{l}0.1479 \\
(0.119)\end{array}$ \\
\hline Model 2 (IV-DiD) & $\begin{array}{c}-0.6197^{* * *} \\
(0.160)\end{array}$ & $\begin{array}{c}0.4906^{* *} \\
(0.231)\end{array}$ & $\begin{array}{r}-0.0748 \\
(0.444)\end{array}$ & $\begin{array}{l}0.0005 \\
(0.001)\end{array}$ & $\begin{array}{c}0.1479^{* * *} \\
(0.056)\end{array}$ & $\begin{array}{r}-0.1268 \\
(0.193)\end{array}$ & $\begin{array}{c}0.7078^{* *} \\
(0.310)\end{array}$ & $\begin{array}{l}0.2565 \\
(0.266)\end{array}$ \\
\hline Controls & $\checkmark$ & $\checkmark$ & $\checkmark$ & $\checkmark$ & $\checkmark$ & $\checkmark$ & $\checkmark$ & $\checkmark$ \\
\hline School FE & $\checkmark$ & $\checkmark$ & $\checkmark$ & $\checkmark$ & $\checkmark$ & $\checkmark$ & $\checkmark$ & $\checkmark$ \\
\hline Year FE & $\checkmark$ & $\checkmark$ & $\checkmark$ & $\checkmark$ & $\checkmark$ & $\checkmark$ & $\checkmark$ & $\checkmark$ \\
\hline Observations & 6,923 & 6,923 & 6,593 & 7,450 & 7,440 & 7,450 & 7,434 & 7,448 \\
\hline Model $1 R^{2}$ & 0.219 & 0.187 & 0.217 & 0.251 & 0.221 & 0.293 & 0.211 & 0.235 \\
\hline First Stage $F$ & 592.72 & 592.72 & 523.89 & 848.92 & 822.08 & 848.92 & 825.20 & 842.61 \\
\hline
\end{tabular}

Robust standard errors in parentheses, clustered by school. F-statistics are Kleibergen-Paap rk Wald F statistics. FE = fixed effects; IV = instrumental variable; V-A = value-added; and MA = master's degree. Control variables include county unemployment rate, median income, student enrollment, percent of students by race/ethnicity, and percent of students economically disadvantaged.

$* * * \mathrm{p}<0.01, * * \mathrm{p}<0.05, * \mathrm{p}<0.1$ 
Table A8: Nonlinear Effects of Charter Growth on TPS Teachers

\begin{tabular}{|c|c|c|c|c|c|c|c|c|}
\hline & $\begin{array}{c}(1) \\
\text { New Teacher }(\%) \\
\end{array}$ & $\begin{array}{c}(2) \\
\text { New to School }(\%)\end{array}$ & $\begin{array}{c}(3) \\
\text { Turnover (\%) }\end{array}$ & $\begin{array}{c}(4) \\
\text { Teacher V-A }\end{array}$ & $\begin{array}{c}5) \\
\text { Teacher Exper }\end{array}$ & $\begin{array}{c}(6) \\
\text { Teacher Lat/Prov }\end{array}$ & $\begin{array}{c}(7) \\
\text { Teacher MA }\end{array}$ & $\begin{array}{c}(8) \\
\text { Teacher Nonwhite }\end{array}$ \\
\hline 0 charters in 10 miles & - & - & - & - & - & - & - & - \\
\hline 1 charter in 10 miles & $\begin{array}{c}-1.3470^{* *} \\
(0.652)\end{array}$ & $\begin{array}{c}3.4885^{* * *} \\
(1.192)\end{array}$ & $\begin{array}{c}4.8353^{* * *} \\
(1.761)\end{array}$ & $\begin{array}{r}-0.0082 \\
(0.006)\end{array}$ & $\begin{array}{l}0.4663 \\
(0.301)\end{array}$ & $\begin{array}{l}0.3266 \\
(0.573)\end{array}$ & $\begin{array}{l}1.7629 \\
(1.862)\end{array}$ & $\begin{array}{l}0.9994 \\
(1.138)\end{array}$ \\
\hline 2-3 charters in 10 miles & $\begin{array}{c}-1.8356^{* *} \\
(0.808)\end{array}$ & $\begin{array}{c}3.0413^{* *} \\
(1.339)\end{array}$ & $\begin{array}{c}5.9292^{* * * *} \\
(2.073)\end{array}$ & $\begin{array}{r}-0.0071 \\
(0.007)\end{array}$ & $\begin{array}{c}1.0239^{* * * *} \\
(0.386)\end{array}$ & $\begin{array}{l}0.3046 \\
(0.748)\end{array}$ & $\begin{array}{c}4.9118^{* *} \\
(2.223)\end{array}$ & $\begin{array}{l}1.9786 \\
(1.400)\end{array}$ \\
\hline 4-6 charters in 10 miles & $\begin{array}{r}-1.4199 \\
(0.929)\end{array}$ & $\begin{array}{l}2.9464^{*} \\
(1.567)\end{array}$ & $\begin{array}{c}6.0777^{* *} \\
(2.563)\end{array}$ & $\begin{array}{c}-0.0084 \\
(0.008)\end{array}$ & $\begin{array}{c}0.9793^{* *} \\
(0.482)\end{array}$ & $\begin{array}{l}-0.3277 \\
(0.954)\end{array}$ & $\begin{array}{c}6.6887^{* *} \\
(2.795)\end{array}$ & $\begin{array}{l}1.8857 \\
(1.642)\end{array}$ \\
\hline 7-9 charters in 10 miles & $\begin{array}{c}-3.0228^{* * * *} \\
(1.062)\end{array}$ & $\begin{array}{c}4.0240^{* *} \\
(1.882)\end{array}$ & $\begin{array}{l}1.7567 \\
(3.016)\end{array}$ & $\begin{array}{l}0.0014 \\
(0.009)\end{array}$ & $\begin{array}{c}1.6206^{* * *} \\
(0.555)\end{array}$ & $\begin{array}{l}-0.8681 \\
(1.130)\end{array}$ & $\begin{array}{c}11.1724^{* * *} \\
(3.207)\end{array}$ & $\begin{array}{c}4.0945^{* *} \\
(1.973)\end{array}$ \\
\hline $10+$ charters in 10 miles & $\begin{array}{c}-3.0013^{* *} \\
(1.171)\end{array}$ & $\begin{array}{c}4.5339^{* *} \\
(2.161)\end{array}$ & $\begin{array}{l}0.1430 \\
(3.361)\end{array}$ & $\begin{array}{l}-0.0054 \\
(0.010)\end{array}$ & $\begin{array}{c}1.7250^{* * * *} \\
(0.603)\end{array}$ & $\begin{array}{l}-0.9018 \\
(1.285)\end{array}$ & $\begin{array}{c}11.5076^{* * *} \\
(3.557)\end{array}$ & $\begin{array}{c}5.5974^{* *} \\
(2.244)\end{array}$ \\
\hline Controls & $\checkmark$ & $\checkmark$ & $\checkmark$ & $\checkmark$ & $\checkmark$ & $\checkmark$ & $\checkmark$ & $\checkmark$ \\
\hline School FE & $\checkmark$ & $\checkmark$ & $\checkmark$ & $\checkmark$ & $\checkmark$ & $\checkmark$ & $\checkmark$ & $\checkmark$ \\
\hline Year FE & $\checkmark$ & $\checkmark$ & $\checkmark$ & $\checkmark$ & $\checkmark$ & $\checkmark$ & $\checkmark$ & $\checkmark$ \\
\hline Observations & 8,522 & 8,522 & 8,129 & 9,186 & 9,168 & 9,186 & 9,160 & 9,182 \\
\hline$R^{2}$ & 0.256 & 0.258 & 0.316 & 0.742 & 0.574 & 0.554 & 0.484 & 0.799 \\
\hline
\end{tabular}

Robust standard errors in parentheses, clustered by school. Control variables include county unemployment rate, median income, student enrollment, percent of students by race/ethnicity, and percent of students economically disadvantaged. Teacher sorting models are estimated excluding 2007, because they require a lagged count of teachers to calculate each dependent variable.

*** $\mathrm{p}<0.01,{ }^{* *} \mathrm{p}<0.05,{ }^{*} \mathrm{p}<0.1$ 
Table A9: Adding Incremental Controls in 10 Mile Intensive Margin Model

\begin{tabular}{|c|c|c|c|c|c|c|c|c|}
\hline & $\begin{array}{c}(1) \\
\text { New Teacher (\%) }\end{array}$ & $\begin{array}{c}(2) \\
\text { New to School }(\%) \\
\end{array}$ & $\begin{array}{c}(3) \\
\text { Turnover (\%) }\end{array}$ & $\begin{array}{c}(4) \\
\text { Teacher V-A }\end{array}$ & $\begin{array}{c}(5) \\
\text { Teacher Exper }\end{array}$ & $\begin{array}{c}(6) \\
\text { Teacher Lat/Prov }\end{array}$ & $\begin{array}{c}(7) \\
\text { Teacher MA }\end{array}$ & $\begin{array}{c}(8) \\
\text { Teacher Nonwhite }\end{array}$ \\
\hline \multicolumn{9}{|c|}{ Intensive Margin: Number of Charters in 10 Miles } \\
\hline School FE Only & $\begin{array}{c}-0.0893 \\
(0.084)\end{array}$ & $\begin{array}{c}0.3553^{* * *} \\
(0.126)\end{array}$ & $\begin{array}{c}-0.1145 \\
(0.225)\end{array}$ & $\begin{array}{l}0.0008 \\
(0.001)\end{array}$ & $\begin{array}{c}0.0648^{*} \\
(0.039)\end{array}$ & $\begin{array}{r}-0.0265 \\
(0.131)\end{array}$ & $\begin{array}{l}0.1570 \\
(0.253)\end{array}$ & $\begin{array}{l}0.0511 \\
(0.181)\end{array}$ \\
\hline School FE and Controls & $\begin{array}{c}-0.1807^{* *} \\
(0.091)\end{array}$ & $\begin{array}{c}0.3134^{* *} \\
(0.155)\end{array}$ & $\begin{array}{l}-0.3089 \\
(0.259)\end{array}$ & $\begin{array}{l}0.0002 \\
(0.001)\end{array}$ & $\begin{array}{c}0.1229^{* * *} \\
(0.047)\end{array}$ & $\begin{array}{r}-0.0275 \\
(0.136)\end{array}$ & $\begin{array}{l}0.5312^{*} \\
(0.292)\end{array}$ & $\begin{array}{l}0.3640^{*} \\
(0.212)\end{array}$ \\
\hline Model 1 (Detrended) & $\begin{array}{c}-0.1817^{* *} \\
(0.091)\end{array}$ & $\begin{array}{c}0.3133^{* *} \\
(0.155)\end{array}$ & $\begin{array}{l}-0.3103 \\
(0.259)\end{array}$ & $\begin{array}{l}0.0002 \\
(0.001)\end{array}$ & $\begin{array}{c}0.1239^{* * *} \\
(0.047)\end{array}$ & $\begin{array}{r}-0.0289 \\
(0.136)\end{array}$ & $\begin{array}{l}0.5316^{*} \\
(0.292)\end{array}$ & $\begin{array}{l}0.3596^{*} \\
(0.212)\end{array}$ \\
\hline Model 2 (IV-DiD) & $\begin{array}{c}-1.4806^{* * *} \\
(0.238)\end{array}$ & $\begin{array}{l}0.5889 \\
(0.380)\end{array}$ & $\begin{array}{l}-0.1746 \\
(0.695)\end{array}$ & $\begin{array}{l}0.0017 \\
(0.003)\end{array}$ & $\begin{array}{c}0.3324^{* * *} \\
(0.115)\end{array}$ & $\begin{array}{l}0.0608 \\
(0.375)\end{array}$ & $\begin{array}{c}2.0152^{* * *} \\
(0.600)\end{array}$ & $\begin{array}{l}0.9290^{*} \\
(0.542)\end{array}$ \\
\hline Observations & 5,606 & 5,606 & 5,322 & 6,010 & 6,001 & 6,010 & 5,998 & 6,009 \\
\hline Model $1 R^{2}$ & 0.225 & 0.192 & 0.224 & 0.250 & 0.224 & 0.301 & 0.214 & 0.234 \\
\hline First Stage $F$ & 505.13 & 505.13 & 522.09 & 867.66 & 856.73 & 867.66 & 856.99 & 865.22 \\
\hline
\end{tabular}

Robust standard errors in parentheses, clustered by school. F-statistics are Kleibergen-Paap rk Wald F statistics, FE = fixed effects; IV = instrumental variable; V-A = value-added; and $\mathrm{MA}=$ master's degree. Control variables include county unemployment rate, median income, student enrollment, percent of students by race/ethnicity, and percent of students economically disadvantaged. 